\title{
Purinergic Signaling in Endometriosis-Associated Pain
}

\author{
Carla Trapero ${ }^{1,2}$ (D) and Mireia Martín-Satué ${ }^{1,2, *}$ \\ 1 Departament de Patologia i Terapèutica Experimental, Facultat de Medicina i Ciències de la Salut, \\ Campus Bellvitge, Universitat de Barcelona, 08907 Barcelona, Spain; ctrapero@ub.edu \\ 2 Institut d'Investigació Biomèdica de Bellvitge (IDIBELL), Oncobell Program, CIBERONC, \\ 08908 Barcelona, Spain \\ * Correspondence: martinsatue@ub.edu
}

Received: 9 October 2020; Accepted: 10 November 2020; Published: 12 November 2020

\begin{abstract}
Endometriosis is an estrogen-dependent gynecological disease, with an associated chronic inflammatory component, characterized by the presence of endometrial tissue outside the uterine cavity. Its predominant symptom is pain, a condition notably altering the quality of life of women with the disease. This review is intended to exhaustively gather current knowledge on purinergic signaling in endometriosis-associated pain. Altered extracellular ATP hydrolysis, due to changes in ectonucleotidase activity, has been reported in endometriosis; the resulting accumulation of ATP in the endometriotic microenvironment points to sustained activation of nucleotide receptors (P2 receptors) capable of generating a persistent pain message. P2X3 receptor, expressed in sensory neurons, mediates nociceptive, neuropathic, and inflammatory pain, and is enrolled in endometriosis-related pain. Pharmacological inhibition of $\mathrm{P} 2 \mathrm{X} 3$ receptor is under evaluation as a pain relief treatment for women with endometriosis. The role of other ATP receptors is also discussed here, e.g., P2X4 and P2X7 receptors, which are involved in inflammatory cell-nerve and microglia-nerve crosstalk, and therefore in inflammatory and neuropathic pain. Adenosine receptors (P1 receptors), by contrast, mainly play antinociceptive and anti-inflammatory roles. Purinome-targeted drugs, including nucleotide receptors and metabolizing enzymes, are potential non-hormonal therapeutic tools for the pharmacological management of endometriosis-related pain.
\end{abstract}

Keywords: endometriosis; ATP; adenosine; P2Y; P2X; ectonucleotidases; pain; inflammation; endometrium; CD73; CD39

\section{Introduction}

Endometriosis is an estrogen-dependent gynecological disease characterized by the presence of endometrial tissue, glands, and stroma outside the uterine cavity, including the ovaries, pelvic peritoneum, and gastrointestinal tract, among other locations. In fact, depending on the location and characteristics, there are three different subtypes of endometriosis: peritoneal, ovarian, and deep infiltrating endometriosis [1]. It is estimated that this debilitating disease affects around $10 \%$ of women of reproductive age, but the true prevalence is difficult to quantify due to its unspecific symptoms and the lack of non-invasive diagnostic techniques that complicates diagnosis and can sometimes lead to misdiagnoses. Moreover, around 20-25\% of women remain asymptomatic [2-4]. Even though pathogenesis of endometriosis is uncertain, the most widely accepted theory is the retrograde menstruation, described by Sampson, that includes three events that have to occur for endometriosis to develop: (i) menstrual blood flow backwards into the pelvic cavity (retrograde menstruation); (ii) the presence of available cells in menstrual debris; and (iii) the ectopic establishment 
and growth of endometrial cells [5]. More research on endometriosis is needed to fill the gaps in our understanding of its pathogenesis so as to help develop new diagnostic and therapeutic tools.

Associated with endometriosis is a chronic inflammatory component necessary for the establishment and progression of endometriotic lesions and which is related with its main symptoms and signs [6-9]. The main clinical features defining this disorder are pain and infertility, with the most common symptoms being cyclic pelvic pain, dysmenorrhea (painful menstrual periods), dyspareunia (painful sexual relations), dysuria (painful urination), and dyschezia (painful defecation) [10]. Different types of pain have been described in endometriosis: nociceptive, inflammatory, neuropathic, and a mixture of all of them. Interestingly, the predominant type of pain, its intensity, and its cyclicity vary between patients without a clear correlation between the scope of endometriotic lesions and pain experience [11]. This turns endometriosis-associated pain into a complex symptom that is difficult to manage.

Current treatments, both pharmacological and surgical, are addressed to providing symptom relief and are mainly focused on complex pain management, without effective results for all patients [11]. Several studies are attempting to overcome these obstacles by identifying molecular targets to develop new therapeutic approaches to improve the quality of life of affected women.

In recent decades, a large body of data has been published on the role of purinergic signaling in different inflammatory pathologies and its possible use as therapeutic target. The purinergic system is the extracellular signaling with biological effects mediated by nucleotides, such as adenosine triphosphate (ATP), and nucleosides, such as adenosine, involved in a wide range of physiological and pathological inflammatory conditions and in pain generation and transmission [12]. The purinergic signaling complex of a cell is sometimes referred to as the purinome [13]. In recent years, several studies have shown the involvement of purinome elements in endometriosis, but few studies have assessed their role as therapeutic targets for the endometriosis-derived chronic pain.

In this review, we aim to highlight the role of purinergic signaling in the pathogenesis and pathophysiology of endometriosis-associated pain. This information may be useful in presenting the molecular mechanisms underlying endometriosis-associated pain and toward the development of novel pharmacological approaches for endometriosis treatment.

\section{Overview of Purinergic Signaling}

Extracellular ATP and adenosine are the main purinergic mediators, with multiple roles in physiology and pathophysiology. The release of endogenous nucleotides and nucleosides into extracellular space by different cells in response to cell injury, necrosis, apoptosis, or various mechanical and chemical stimuli represents the beginning of the purinergic signaling cascade, which eventually induces an inflammatory response [12,14].

Under physiological conditions, extracellular ATP concentrations are low (submicromolar levels). However, with the release of endogenous ATP under situations such as inflammation, there is a marked increase of these levels [15].

To avoid sustained ATP signaling and the adverse effects of increased extracellular ATP levels, ectonucleotidases act extracellularly by degrading ATP into adenosine. Ectonucleotidases are specialized nucleotide-hydrolyzing enzymes, broadly expressed at the cell surface of many tissues, which, acting alone or sequentially, control nucleotide and nucleosides levels in the extracellular milieu (Figure 1). Four families of ectonucleotidase have been described: (i) the ectonucleoside triphosphate diphosphohydrolase (ENTPDase) family (also known as CD39 family), with NTPDase1 (CD39), $-2,-3$, and -8 as plasma membrane-bound members, which hydrolyze extracellular ATP to adenosine diphosphate (ADP), and ADP to adenosine monophosphate (AMP); (ii) the ectonucleotide pyrophosphatase/phosphodiesterase (ENPP) family, which converts ATP to AMP and inorganic pyrophosphate (PPi); (iii) the $5^{\prime}$-nucleotidase family, with only one membrane-bound member, the ecto-5'-nucleotidase, also known as CD73, which hydrolyzes AMP to adenosine; and (iv) the alkaline 
phosphatase (ALP) family, able to hydrolyze adenine nucleotides and pyrophosphate, releasing inorganic phosphate $(\mathrm{Pi})[12,16]$.

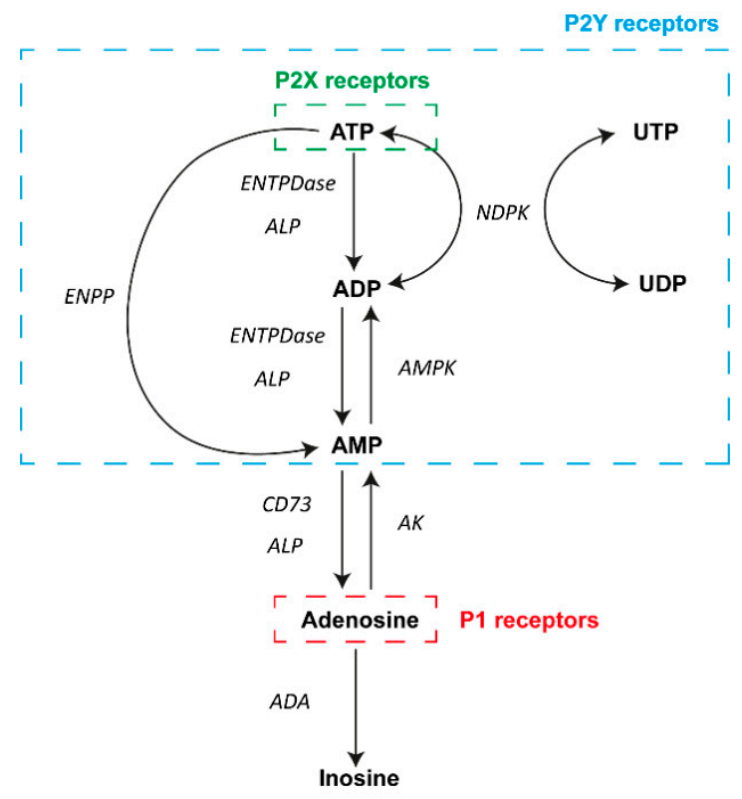

Figure 1. Diagram of the main elements of purinergic signaling. In the extracellular milieu, adenosine and nucleotides can activate P1 and P2 receptors on the surface of a wide variety of cell types. A number of different nucleotides can activate P2Y receptors (blue box), and ATP can also activate $\mathrm{P} 2 \mathrm{X}$ receptors (green box). In contrast, adenosine actions involve the activation of P1 receptors (red box). Different enzymes are involved in the metabolism of adenosine and ATP in the process of achieving transient signaling. Abbreviations: adenosine triphosphate, ATP; adenosine diphosphate, ADP; adenosine monophosphate, AMP; uridine triphosphate, UTP; uridine diphosphate, UDP; ectonucleoside triphosphate diphosphohydrolase family, ENTPDase; alkaline phosphatase family, ALP; ectonucleotide pyrophosphatase/phosphodiesterase family, ENPP; ecto-5'-nucleotidase, CD73; nucleoside diphosphate kinase, NDPK; AMP-activated protein kinase, AMPK; adenosine kinase, AK; adenosine deaminase, ADA.

Adenosine also has important biological functions. In general, adenosine has been linked mainly to an anti-inflammatory effect. There are two enzymes responsible for adenosine metabolism: adenosine deaminase (ADA) and adenosine kinase (AK). ADA is a cytoplasmic enzyme but also an ectoenzyme that regulates intra- and extracellular adenosine levels, catalyzing the adenosine deamination yielding inosine [12]. As ectoenzyme, ADA is expressed as a soluble form or as membrane-associated enzyme-forming complexes with CD26/dipeptidyl peptidase IV in humans. AK is a cytosolic enzyme that catalyzes the phosphorylation of intracellular adenosine to AMP [12].

Once in the extracellular microenvironment, adenosine and nucleotides can activate two different purinergic receptor families, $\mathrm{P} 1$ and $\mathrm{P} 2$, respectively, which are widely and differentially expressed in the surface of most cells. Adenosine binds to $P 1$ receptors, which are $G$ protein-coupled receptors classified into four subtypes: $A_{1}, A_{2 A}, A_{2 B}$, and $A_{3}$ [17]. These receptors mainly act via adenylate cyclase (AC) activity, modulating cyclic AMP (cAMP) production. The stimulation of the $A_{2 A}$ and $A_{2 B}$ receptors induces activation of $A C$, increasing second-messenger cAMP levels. In contrast, the activation of the $A_{1}$ and $A_{3}$ receptors inhibits $A C$, causing a decrease in cAMP production [17]. Furthermore, $A_{3}$ and $A_{2 B}$ receptors lead to the activation of phospholipase $C$ (PLC) and an increase in intracellular calcium levels $[18,19]$. Moreover, $\mathrm{A}_{1}$ receptor is involved in the opening of $\mathrm{K}^{+}$channels $[18,19]$. Cation mobilization triggered by adenosine receptors leads to transmission and modulation of pain. In addition, adenosine receptors stimulate mitogen-activated protein kinases (MAPK), regulating 
growth and proliferation, apoptosis, necrosis, and inflammation, essential for the development of endometriosis [20].

In addition, $\mathrm{P} 2$ receptors are nucleotide-selective and include P2X and P2Y receptor subtypes. The ionotropic P2X receptors, comprising seven subtypes (P2X1-P2X7), are ligand-gate ion channels strictly activated by extracellular ATP to mediate $\mathrm{K}^{+}$efflux, and $\mathrm{Na}^{+}$and $\mathrm{Ca}^{2+}$ influx, which mainly mediate short-term (acute) purinergic signaling, and which play an important role as mediators of fast excitatory neurotransmission in the central and peripheral nervous system $[17,21]$. The metabotropic P2Y receptors are $G$ protein-coupled receptors that activate PLC- $\beta$ (P2 $Y_{1}, P_{2} Y_{2}, P 2 Y_{4}, P_{2} Y_{6}$, and $\left.\mathrm{P}_{2} \mathrm{Y}_{11}\right)$ or inhibit AC (P2Y11-14). The P2Y receptors have distinctive nucleotide preferences and, based on this, they can be divided in three groups: (i) adenine nucleotide-preferring receptors, mainly responding to ATP (P2Y $, \mathrm{P}_{2} \mathrm{Y}_{2}, \mathrm{P}_{2} \mathrm{Y}_{4}$, and $\left.\mathrm{P} 2 \mathrm{Y}_{11}\right)$ and ADP (P2Y $\left., \mathrm{P}_{2} \mathrm{Y}_{12}, \mathrm{P}_{2} \mathrm{Y}_{13}\right)$; (ii) uracil nucleotide-preferring receptors, activated by UTP (P2Y, $\mathrm{P}_{2} \mathrm{Y}_{4}$, and $\left.\mathrm{P}_{2} \mathrm{Y}_{6}\right)$ and/or UDP $\left(\mathrm{P}_{2} \mathrm{Y}_{6}\right.$ and $\mathrm{P}_{2} \mathrm{Y}_{14}$ ); and (iii) the $\mathrm{P}_{2} \mathrm{Y}_{14}$ nucleotide sugar-preferring receptor, responding to UDP sugars, such as UDP-glucose and UDP-galactose [17,22,23]. P1 and P2Y G protein-coupled receptors are predominantly involved in long-term (trophic) purinergic signaling, such as that found in remodeling, repair, and regeneration events in response to injury. P1 and P2Y receptors are involved in the regulation of proliferation, differentiation, motility, migration, and cell death [21], which are essential processes for the establishment of endometriotic lesions and the progression of endometriosis.

Correct expression and function of the purinome are essential to maintaining tissue homeostasis. Changes in ATP/adenosine balance and in the purinergic receptor activation state can alter the behavior of a wide range of cell types. These changes can trigger a pathological state or promote the progression of a disease, as may occur in endometriosis.

\section{Purinergic Signaling in Eutopic and Ectopic Endometrial Tissue}

Extracellular purines and pyrimidines play multiples roles in fertilization and embryo development $[24,25]$. This is made possible by different elements of the purinome, such as purinergic receptors and ectonucleotidases, present in both male and female reproductive organs [26-33].

Endometrium, the innermost layer of the uterus, contains the surface epithelium, the glandular epithelium, and a vascularized stroma. It is a dynamic tissue undergoing repetitive cycles of regeneration and degeneration in which a certain degree of inflammation is physiological. Purinergic signaling plays a role in both inflammation and reproduction and contributes to correct endometrial function. Therefore, it is not surprising that any change in purinergic signaling can alter uterine function and fertility in women, as happens in endometriosis. In addition, purinergic signaling is involved in the control of a number of cell events, such as cell proliferation, migration, and survival, but it is also seen in phenomena such as angiogenesis and fibrosis (reviewed in [34-36]), thus becoming a candidate pathway for playing a causative role in the pathogenesis and development of this disease.

Therefore, the characterization of the purinome elements of eutopic endometrium and endometriotic lesions is essential in order not only to elucidate the role of purinergic signaling in the pathogenesis, but also to identify the main symptoms and signs of endometriosis and new therapeutic targets. Moreover, knowledge of the microenvironment of ectopic lesions can improve understanding of the generation and neurotransmission of pain signals in endometriosis. We present below current knowledge on the expression of ectonucleotidases, the main elements of the purinome regulating the levels of nucleotides and nucleosides in eutopic and ectopic microenvironments.

\section{Ectonucleotidases in the Eutopic and Ectopic Endometria of Women with Endometriosis}

Ectonucleotidases are hormone-sensitive enzymes that vary their expression in the endometrium throughout the menstrual cycle [26]. NTPDase2, NTPDase3, NPP1, NPP3, ALP, CD26, and CD73 are expressed by endometrial epithelial cells, while NTPDase1, NTPDase2, and CD73 have been detected in endometrial stromal cells [26]. Although the ectonucleotidases studied to date are mainly present in the endometrial epithelium, most of the changes detected in endometriosis occur in the stroma [37]. 
Changes in eutopic endometrium of women with endometriosis in comparison with the endometrium of women without the pathology have been detected [26,37]. Moreover, differences between the different types of endometriotic lesions have been described [37]. One notable change in endometriosis is the expression of NPP3. Several studies of NPP3 expression in endometrial tissue have localized the protein in epithelial cells, with changes along the cycle $[26,38,39]$. In endometriosis, however, NPP3 is found to be expressed by the stroma, as well as the epithelium, in both eutopic and ectopic endometrial tissues [37]. This de novo expression of NPP3 points to its use as a putative histopathological marker of the disease. It has to be noted that although there is no protein expression of NPP3 in the endometrial stroma of women without endometrial pathology, Boggavarapu et al. detected more than double the levels of NPP3 mRNA in the stroma compared to glandular compartment [40]. All of this points to post-translational regulation of protein levels that needs to be further studied. This increased expression of NPP3 in endometrial tissue coincides with the increased ectonucleotidase activity detected in the fluid content of ovarian endometriomas [41]. These results suggest an increase in ATP metabolism, with a concomitant increase in extracellular adenosine levels, as observed in some cancers, in which high levels of adenosine in the tumor microenvironment induce suppression of the local immune response [42,43]. Conversely, the detection of one hundred times higher levels of ADA in the contents of endometriomas refutes the idea of adenosine accumulation [44]. Moreover, the great decrease in, or even the total loss, of the CD39-CD73 axis in endometrial tissue in endometriosis further suggests that extracellular adenosine synthesis is rather limited. [37]. In fact, these data suggest a relation between extracellular ATP accumulation and the severity and progression of endometriosis, since the loss of CD39-CD73 is related to deep infiltrating endometriosis, the most severe form of the illness with high recurrence rates and a high level of associated pain [45,46].

The consequences of the increase in extracellular ATP levels and the subsequent activation of purinergic signaling through P2 receptors in endometriosis-associated pain are discussed throughout this review.

\section{Involvement of Purinergic Signaling in Endometriosis-Associated Pain}

\subsection{Endometriosis-Associated Pain}

Pain is recognized as the most common symptom and the primary reason for medical assistance in women with endometriosis. In fact, up to $80 \%$ of patients present chronic pain, the most common forms being dysmenorrhea, non-cyclical pelvic pain (chronic pelvic pain), dyspareunia, dysuria, and dyschezia [2]. Endometriosis-associated pain has, in turn, negative effects on women's mental health, including anxiety and depression, thereby altering their quality of life and that of their loved ones [47,48]. For this reason, there is an urgent need to define the molecular mechanisms underlying endometriosis-associated pain to uncover therapeutic targets to minimize the suffering and raise the quality of life of affected women.

Endometriosis-associated pain is complex, and the underlying mechanisms seem to be related to the activation of the peripheral nervous system, involved in nociceptive (a response to a noxious stimulus), inflammatory (due to tissue damage and inflammatory response), and neuropathic (due to a lesion in somatosensory nervous system) pain, and central nervous systems, related with sensitization and hyperalgesia processes [49,50]. The stage of endometriosis, as classified by the American Society of Reproductive Medicine (ASRM), poorly correlates with the degree of pain or symptoms severity, thus hampering clinical management [11].

In recent years, many articles concerning endometriosis-associated pain and treatments for pain-relief have been published (reviewed in [10,11,49,51-63]); independently, the purinergic mechanisms involved in pain (reviewed in $[18,64-70]$ ) are also being studied. However, purinergic signaling in relation to endometriosis-associated pain has yet to be fully explored. In the following section, we look at the involvement of the purinergic signaling in pain, especially in peripheral, but also in central processes, in the context of endometriosis. 


\subsubsection{The Pain Pathway}

The neural process of pain starts with a peripheral noxious stimulus detected by the nociceptors on small diameter sensory afferent nerves (fibers $\mathrm{A} \delta$ and $\mathrm{C}$ ) and its transduction into an electric signal. These neurons, which innervate viscera, have the cell bodies in the dorsal root ganglia (DRG) and reach the lamina I-II of the dorsal spinal cord. This information is transmitted along the spinal cord to the brain, where the unpleasant experience called pain is generated. Although multiple painful conditions have their origin in the sensitization and excitation of neurons, immune and glial cells also play key roles in the generation and maintenance of pain signaling [71,72]. Indeed, the pain perceived can be altered, amplified, or reduced by many molecules, including ATP, released from these non-neuronal cells through different mechanisms required for the transition from acute to chronic pain [72,73]. ATP is a peripheral mediator of pain involved in the initiation of this pain perception.

There is evidence that endometriotic lesions are innervated. This innervation is mainly sympathetic, and sensory nerve fibers play a pivotal role in endometriosis-associated pain [74-78]. The inflammation, concomitant to the initial establishment of an endometriotic focus outside the uterus, activates sensory afferent neurons innervating adjacent visceral structures, transmitting the noxious stimulus to the spinal dorsal horn and causing pain. Moreover, local inflammatory cells release neurotrophic factors encouraging the new innervation and cytokines that lead to the implantation of endometrial ectopic cells. Neuronal and non-neuronal cells of endometriotic lesions can release ATP that in turn regulates the action of these cells. For example, the release of ATP and neurotransmitters by afferent neurons also activates spinal glial cells, contributing to central sensitization and overstated pain.

Endometriotic foci present cyclic proliferative and destructive phases similar to the endometrium. During the breakdown of a part of a lesion, high levels of ATP are released in the lesion microenvironment, acting as an acute danger signal on sensory nerve endings of the lesion. Moreover, this internal bleeding in the ectopic locations often leads to local inflammatory reactions that promote the inflammatory state and the release of molecules involved in the pain signaling pathway. In addition, ATP has the potential to modify the pain signaling by activation of pre- and post-synaptic P2 receptors. The two classes of $\mathrm{P} 2$ receptors are involved in pain: P2X receptors in short-term neurotransmission responses and $\mathrm{P} 2 \mathrm{Y}$ receptors in the slow and continuous pain signaling.

The high levels of extracellular ATP in the ectopic milieu, together with the loss of the CD39-CD73 axis, turns purinergic signaling into a precious source of possible therapeutic targets for endometriosis-associated pain treatment. The role of ATP and adenosine in the pain signaling pathway in the context of endometriosis is reviewed in detail below.

\subsubsection{P2X Receptors in Primary Sensory Neuron: The Outset of Nociception}

$P 2 X 3$ and P2X2/3 receptors. P2X3 and P2X2/3 receptors are expressed in terminals of nociceptive fibers and in the sensory neurons of the central nervous system. Homomeric P2X 3 receptors mediate transient nociceptive responses through rapidly desensitizing current, and heteromeric P2X2/3 receptors mediate sustained nociceptive responses through a slowly desensitizing current [79]. They mediate neuropathic pain, including inflammatory pain, in acute and chronic processes, and are involved in hyperalgesia and allodynia [80]. In fact, sensory neurons which express transient receptor potential vanilloid-1 (TRPV1) channels and/or P2X3 receptors are essential for the initiation and transduction of nociception and the signaling of pain. Both TRPV1 and P2X3 induce $\mathrm{Ca}^{2+}$ influx which activates a cascade of changes, including the phosphorylation of ion channels with the consequent increase in the excitability of sensory neurons.

Estrogens upregulate the expression of both the cation channel TRPV1 and P2X3 receptors of nerve fiber terminals in endometriosis [81]. The implication of TRPV1 in endometriosis-associated pain is clear, but the precise role of $\mathrm{P} 2 \mathrm{X} 3$ is still under study, although there is increasing evidence of its central role in the onset of pain sensation in endometriosis. Ding et al. detected the expression of P2X3 in endometriotic epithelial and stromal cells but also in the sensory nerve fibers within endometriotic 
lesions [82]. Moreover, they positively correlated the levels of P2X3 receptor in endometriotic lesions with the severity of pain [82].

The activation of $\mathrm{P} 2 \mathrm{X} 3$ receptor in nerve fibers leads to the release of endogenous ATP via pannexin-1 hemichannels, triggering the activation of P2 receptors of sensory nerve fibers [83]. In addition, this ATP efflux can be enhanced by nerve growth factors [83]. Persistent extracellular ATP with the concomitant $\mathrm{P} 2 \mathrm{X} 3$ and $\mathrm{P} 2 \mathrm{X} 2 / 3$ receptor activation has been linked to the induction and the early maintenance phases of allodynia, a clinical manifestation of chronic pain present in endometriosis $[84,85]$.

In rats, the induction of endometriosis produces thermal and mechanical hyperalgesia. Moreover, endometriosis causes the elevation of endogenous ATP content and P2X3 receptor expression in endometriotic and DRG tissues, which correlate with the severity of hyperalgesia in these animals [86]. In fact, the implication of ATP and P2X3 in endometriosis-associated pain was also confirmed, since administration of A-317491, a selective P2X3 receptor antagonist, attenuated endometriosis-associated pain in rats [87].

Study of the upregulation of P2X3 receptor in endometriosis-related pain showed ATP and ADP, but not UTP, as the effector molecules of this process [86]. In accordance with P2 receptor affinities, $\mathrm{P}_{2} \mathrm{Y}_{1}, \mathrm{P}_{2} \mathrm{Y}_{12}$, and/or $\mathrm{P}_{2} \mathrm{Y}_{13}$ receptors could be responsible for this upregulation. Ding et al. determined that $\mathrm{P} 2 \mathrm{X} 3$ upregulation by ADP is mediated by the activation of the transcription factors ATF3 and AP-1 [86]. Moreover, based on the literature, they discussed the possible role of $\mathrm{P}_{2} \mathrm{Y}_{1}$ as the promoter of this pathway, but functional studies are needed to confirm this point [86].

Hence, extracellular ATP seems to have a close relationship with initiation, amplification, and maintenance of endometriosis-related pain [87]. In a persistent damaging inflammatory microenvironment, such as the one generally found in the peritoneum of women with endometriosis, high levels of inflammatory mediators are detected. Endometrial cells and immune cells in the ectopic lesions secrete different inflammatory mediators such as interleukin (IL)- $1 \beta, \mathrm{IL}-6$, and tumor necrosis factor alpha (TNF- $\alpha)[71,88]$, as well as growth factors such as vascular endothelial growth factor (VEGF), neurotropin nerve growth factor (NGF), and brain-derived neurotrophic factor (BDNF), often promoted by the presence of high estrogen levels [71,89-91]. These factors not only promote the inflammatory state and the aberrant neuroangiogenic milieu, but are also involved in processes that reduce the threshold of ion channels of sensory fibers, increasing their membrane excitability and the expression of receptors involved in nociception, thus favoring the activation of pain signaling pathway. These molecules promote the release of endogenous ATP during inflammation with the subsequent activation of $\mathrm{P} 2 \mathrm{X} 3$ and $\mathrm{P} 2 \mathrm{X} 2 / 3$ receptors, allowing $\mathrm{Ca}^{2+}$ influx and depolarization in nearby nociceptive fibers of the endometriotic foci and leading to the sensitization of sensory neurons, which send the pain message to the central nervous system. Therefore, ATP triggers the purinergic signaling cascade in nervous cells involved in pain symptoms. However, P2X3 activation by ATP as a potential action generator is only the beginning of ATP participation in the pain signaling pathway, as shown below.

The activation of the receptors tyrosine kinase A (TrkA), p75, and VEGFR2 in primary sensory neurons mediated by NGF and VEGF, secreted by endometriotic and immune cells, triggers the upregulation of $\mathrm{P} 2 \mathrm{X} 3$, causing repeated neuronal sensitization by increased P2X3 receptor signaling and provoking a persistent sensation of pain [92,93]. Moreover, NGF plays a role in the production of the neuropeptide substance P (SP) and calcitonin gene-related peptide (CGRP), which sensitize the sensory nerve fibers, stimulate the immune system, cause the degranulation of mast cells, and promote fibrosis of the lesion through activation of their receptors neurokinin-1 receptor (NK1R) and calcitonin gene-related peptide receptor (CGRPR), respectively [94,95]. Moreover, the high levels of estrogens detected in the microenvironment of endometriotic lesions trigger the degranulation and secretion of NGF by mast cells [96]. Mast cell granules contain inflammatory mediators and neuro-sensitizing molecules including IL-1 $\beta$, IL- 6 , TNF- $\alpha$, and histamine, which, once released into the endometriotic milieu, encourage nerve sensitization and the inflammatory state [97]. 


\subsubsection{P2Y Receptors in Primary Sensory Neuron: The Modulation of Nociception}

Primary sensory neurons also express P2Y receptors and their role is mainly pain modulation. P2Y receptors potentiate pain induced by chemical or physical stimuli via capsaicin-sensitive TRPV1 channels and facilitate the P2X receptor-mediated currents [98,99].

$P 2 Y_{1}$ and $P 2 Y_{2}$ receptors. Activation of $P 2 Y_{1}$ and $P 2 Y_{2}$ receptors is involved in the activation of TRPV1 channels of nociceptors. Although in humans it is not clear, in rats, upregulation of TRPV1 channel expression by P2Y $_{1}$ receptors is mediated via p38/MAPK $[100,101]$. Therefore, it is probably the case that ATP and ADP are involved in short- and long-term effects in nociceptors. On the one hand, they can play a role in the modulation of $\mathrm{Ca}^{2+}$ influx that potentiates the sensitization of sensory neurons, while, on the other hand, they may be involved in the long-term nociceptor changes that produce hyperalgesia through the upregulation of TRPV1 channels. Moreover, as stated above, $\mathrm{P}_{2} \mathrm{Y}_{1}$ may also play a role in the upregulation of $\mathrm{P} 2 \mathrm{X} 3$ receptor ion channel in endometriosis-associated pain [86]. In

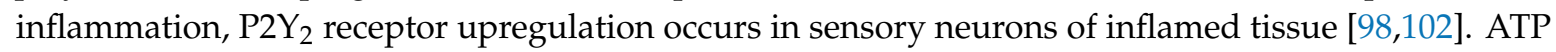
(and UTP) stimulus on $\mathrm{P}_{2} \mathrm{Y}_{2}$ receptors activates TRPV1 channels [103]. This points to the contribution of ATP to chronic inflammatory pain, and therefore, endometriosis.

\subsubsection{P2X4 and P2X7 in Macrophage-Nerve Interaction: The Base of Inflammatory Pain}

As a consequence of the inflammatory process, large numbers of macrophages, mastocytes, and neutrophils are recruited in the endometriotic focus and macrophages infiltrate DRG [71,96,104]. Macrophages are among the most numerous immune cells in endometriotic lesions. They produce pro-inflammatory cytokines such as IL- $1 \beta$, TNF- $\alpha$, and IL-6, which intervene in the pain phenomena [105] and have a role in endometriosis-associated pain (reviewed in [71]). The activation of P2 receptors expressed by immune cells, such as P2X7 and P2X4 receptors in macrophages [106], allows the activation of the immune system via ATP and leads to the production of cytokines, thus maintaining the persistent inflammatory state. Moreover, the activation of macrophage P2X4 receptors is involved in the release of COX-dependent release of prostaglandin E2 (PGE2), mediated by cytosolic phospholipase A2 (cPLA2) [107]. PGE2 is involved in the sensitization of primary sensory neurons [107]. The interaction among endometrial cells, inflammatory cells, and peripheral sensory neurons at the ectopic foci, and the ATP-mediated molecular pathways, are represented in Figure 2.

\subsubsection{P2 Receptors in Activated Microglia: The Modulation of Pain Transmission}

Endometriosis-associated pain is not only inflammatory but also neuropathic [82,108]. Nerve damage and persistent stimulation of peripheral fibers can lead to the secretion of inflammatory neurotransmitters and neuromodulators from nerve fibers, including ATP, which acts on glial cells. In the meantime, glial cells react, becoming the main source of neuroactive substances, including pro-inflammatory cytokines, trophic factors, and neurotransmitters (such as ATP), which regulate neuronal excitability and are fundamental to the transition from acute to chronic pain.

P2 receptors are present in the surface of activated spinal microglia and are involved in the recruitment and activation of microglia and the interaction between neurons and microglia (summarized in Figure 3). All of these play important roles in neuropathic pain, mainly in allodynia and hyperalgesia, and in neuroinflammation. 


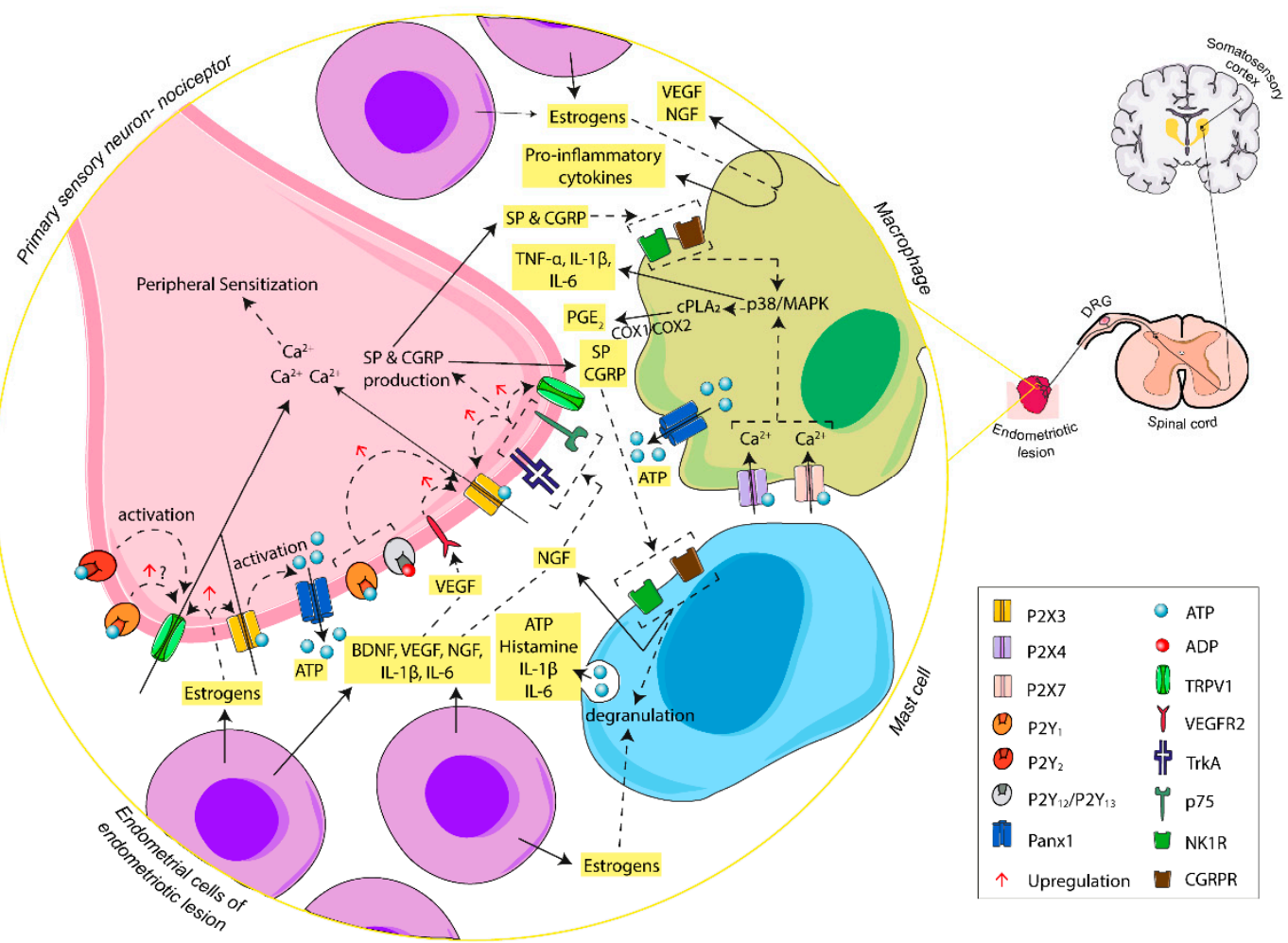

Figure 2. Schematic summary of the involvement of ATP, through activation of P2X and P2Y receptors, in the initiation of endometriosis-associated pain. In the endometriotic lesion, ATP, released by different cell sources, carries out $\mathrm{Ca}^{2+}$ influx via $\mathrm{P} 2 \mathrm{X} 3$ receptor activation at the endings of primary sensory neurons, triggering a cascade of changes that increase the excitability of afferent sensory neurons. The activation of $\mathrm{P} 2 \mathrm{Y}$ receptors potentiates the action of $\mathrm{P} 2 \mathrm{X} 3$ receptor and TRPV1, triggering induction of nociception and the maintenance of overstated pain. Moreover, ectopic endometrial cells and inflammatory cells of the lesion release inflammatory mediators that boost nerve sensitization and promote the inflammatory state typical of women with endometriosis. Abbreviations: adenosine triphosphate, ATP; adenosine diphosphate, ADP; pannexin-1, Panx1; brain-derived neurotrophic factor, BDNF; neurotropin nerve growth factor, NGF; tyrosine kinase A receptor, TrkA; p75 neurotrophin receptor, p75; vascular endothelial growth factor, VEGF; vascular endothelial growth factor receptor 2, VEGFR2; interleukin-1 beta, IL-1 $\beta$; interleukin-6, IL-6; tumor necrosis factor alpha, TNF- $\alpha$; substance P, SP; neurokinin-1 receptor, NK1R; calcitonin gene-related peptide, CGRP; calcitonin gene-related peptide receptor, CGRPR; transient receptor potential vanilloid-1 channel, TRPV1; p38 mitogen-activated protein kinases, p38/MAPK; cytosolic phospholipase A2, cPLA 2 ; prostaglandin E2, PGE2; cyclooxygenase-1 and -2 , COX-1/COX-2; dorsal root ganglia, DRG.

Apparently, the activation of microglial P2 receptors, particularly P2X4 and P2X7, promotes neuronal excitability. Therefore, blocking microglia-neuron signaling must be considered as a possible therapeutic strategy for treating endometriosis-associated pain.

$P 2 X 4$ receptor. The role of the $\mathrm{P} 2 \mathrm{X} 4$ receptor in activated microglia in endometriosis-associated pain has not yet been studied, but P2X4 receptor involvement in neuropathic pain is clear. Following peripheral nerve injury, P24 receptor is expressed by the microglia of the dorsal horn [109]. The activation of P2X4 receptor causes $\mathrm{Ca}^{2+}$ flux and p38/MAPK activation, which promotes the synthesis and release of BDNF, a key molecule for maintaining pain hypersensitivity. ATP-mediated BDNF release from activated microglia, via its receptor TrkB, mediates the downregulation of the $\mathrm{K}^{+} / \mathrm{Cl}^{-}$ cotransporter KCC2 in dorsal horn neurons. KCC2 maintains the anion gradient necessary for the inhibitory actions of gamma-aminobutyric acid (GABA) through gamma-aminobutyric acid A receptor $\left(\mathrm{GABA}_{\mathrm{A}} \mathrm{R}\right) . \mathrm{KCC} 2$ downregulation increases intracellular chloride levels, allowing the accumulation of anions in dorsal horn neurons. Meanwhile, GABA is released from inhibitory interneurons. GABA 
activates the $\mathrm{GABA}_{\mathrm{A}} \mathrm{R}$ on dorsal horn neurons with the subsequent chloride outflow, causing the depolarization of the second order neurons. Hence, BDNF alters the chloride gradient of dorsal horn neurons, triggering a decrease in the inhibitory control of the GABAergic interneurons. Consequently, there is an increase in dorsal horn neuron excitability that enables low threshold information to gain access to nociceptive circuits. This evokes pain transmission and neuropathic pain [109-111]. In addition, P2X4 receptor, through p38/MAPK activation, leads to the synthesis and release of pro-inflammatory cytokines and increases the expression of COX, enhancing PGE2 levels, involved in pain-related inflammatory responses and dorsal horn neuronal excitability $[112,113]$. It is noteworthy, however, that P2X4 is not the only one. The activation of P2X7 (by ATP) and P2 $\mathrm{Y}_{12}$ and $\mathrm{P} 2 \mathrm{Y}_{13}$ receptors (by ADP) also induces microglial pro-inflammatory cytokine release, upregulating excitatory synaptic transmission in the dorsal horn and participating in neuropathic pain [112,114-116]. Moreover, these P2 receptors can be activated by the release of ATP by spinal astrocytes, promoting cytokine production and a pro-inflammatory milieu [117].

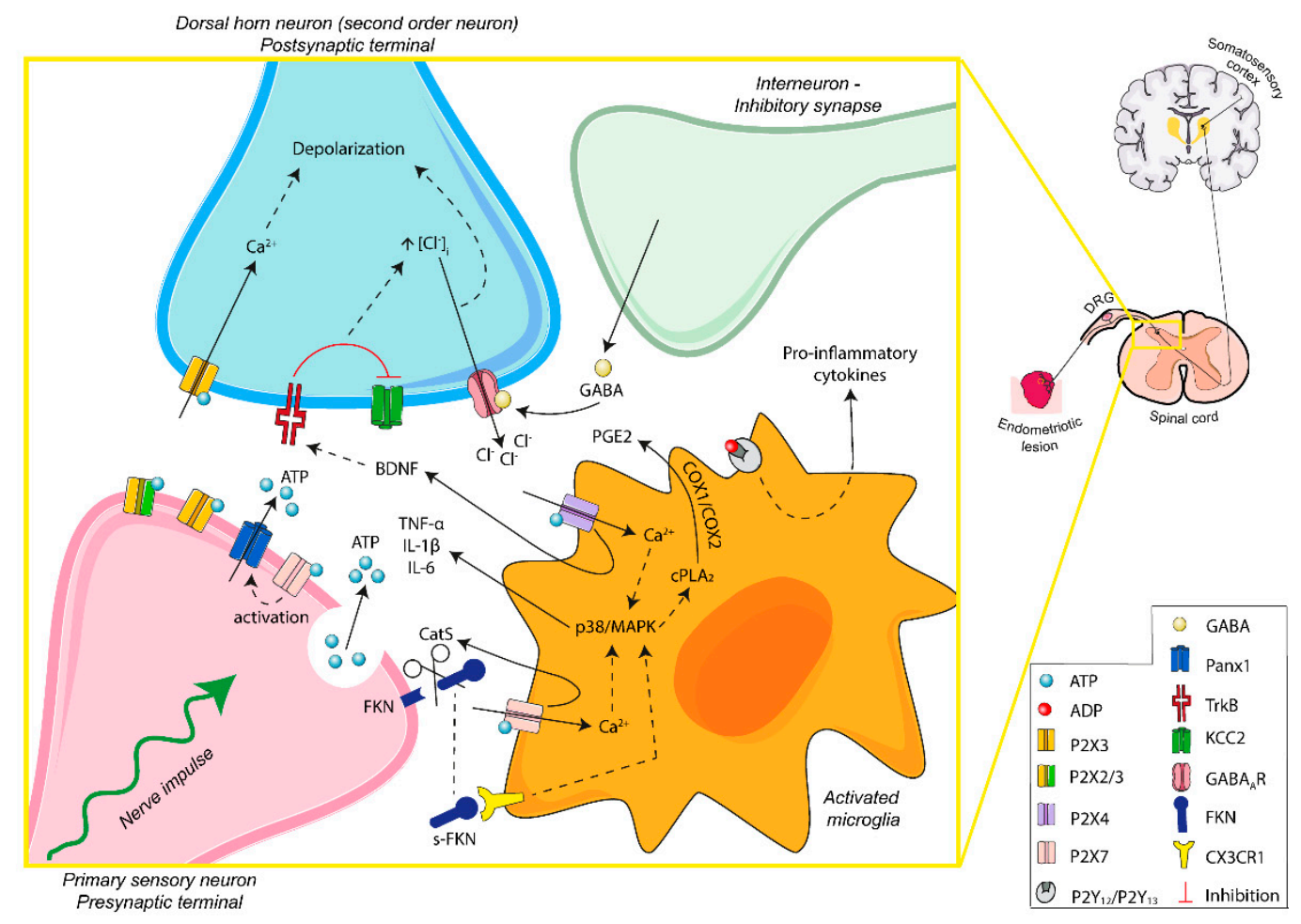

Figure 3. Schematic overview of ATP signaling in microglia-nerve interaction in endometriosis-associated pain. Persistent stimulation of peripheral fibers leads to the release of ATP into the synaptic space. The activation of $\mathrm{P} 2 \mathrm{X} 3$ receptors of postsynaptic terminals induces excitability of dorsal horn neurons. Moreover, P2X4 and P2X7 receptors of activated microglia are involved in the secretion of neuroactive substances, contributing to the microglia-nerve interaction needed for central sensitization and modulation of the sensation of pain. ATP-mediated signaling is fundamental in the transition from acute to chronic pain, including endometriosis-related neuropathic and inflammatory pain. Abbreviations: adenosine triphosphate, ATP; adenosine diphosphate, ADP; pannexin-1, Panx1; brain-derived neurotrophic factor, BDNF; interleukin-1 beta, IL-1 $\beta$; interleukin-6, IL-6; tumor necrosis factor alpha, TNF- $\alpha$; gamma-aminobutyric acid, GABA; gamma-aminobutyric acid A receptor, $\mathrm{GABA}_{\mathrm{A}} \mathrm{R}$; p38 mitogen-activated protein kinases, p38/MAPK; cytosolic phospholipase $\mathrm{A} 2, \mathrm{CPLA}_{2}$; prostaglandin E2, PGE2; cyclooxygenase-1 and -2, COX-1/COX-2; fractalkine, FKN; soluble-fractalkine, s-FKN; cathepsin S, CatS; CX3C chemokine receptor 1, CX3CR1; tyrosine kinase B receptor, TrkB; potassium-chloride cotransporter 2, KCC2; dorsal root ganglia, DRG.

$P 2 X 7$ receptor. $\mathrm{P} 2 \mathrm{X} 7$ receptor functions as an ion channel, but sustained stimulation with large amounts of extracellular ATP induces its conformation as nonselective large pores in cell membrane. It 
is present in microglia and plays a role in the maintenance of neuropathic pain. Specific inhibition of P2X7 receptor pore formation, without affecting its cation channel activity, reduces chronic pain [118].

In microglia, the activation of P2X7 receptor causes the release of the enzyme Cathepsin S (CatS). Extracellular CatS splits the chemokine domain of neuronal membrane-bound fractalkine (FKN) present in dorsal horn neurons. Soluble-FKN (s-FKN) interacts with microglia CX3C chemokine receptor 1 (CX3CR1), stimulates p38/MAPK, and promotes the release of cytokines that sensitize the second order neurons of the sensory pathway [119-121]. Liu et al. showed an increase in the expression of FKN/CX3CR1/p38/MAPK and in the amount of microglia in the dorsal horn of the sciatic nerve, in an endometriosis rat model [122]. This microglia-nerve crosstalk plays a role in central sensitization and could explain one of the mechanisms associated with hypersensitivity and allodynia in endometriosis. Moreover, increased levels of s-FKN were found in the peritoneal fluid of women with endometriosis [123]. In the ectopic endometrial lesions of a sciatic endometriosis model in rats, increased levels of FKN and s-FKN as well as CX3CR1 have been detected, with a positive correlation with the severity of hyperalgesia [122]. In ectopic lesions, membrane-bound FKN was found in the macrophage surface, whereas CX3CR1 was present in nerve fibers, specifically in Schwann cells. As previously noted, macrophages express P2X7 receptor, which could be an essential piece in FKN cleavage in the endometriotic foci. s-FKN can act as a CX3CR1 ligand as well as being a potent chemoattractant that would favor the development and maintenance of the inflammatory microenvironment in the ectopic lesion, mainly around nerve fibers. On the other hand, a direct interaction between macrophage membrane-bound FKN and CX3CR1 of Schwann cells has been suggested, which could cause myelin phagocytosis and activation of Schwann cells involved in peripheral sensitization in ectopic lesions. Therefore, P2X7 receptor could contribute to peripheral and central hypersensitivity in endometriosis [122].

Although microglial P2X7 receptor activation by presynaptic neurons is mainly related to the release of pro-inflammatory cytokines, it also causes more ATP release into the dorsal horn microenvironment. This is made possible by the increase in the intracellular calcium resulting from P2X7 action that activates pannexin-1. The increasing extracellular ATP levels potentiate purinergic signaling in pain effectors and induce chronification of pain [124].

\subsubsection{Adenosine and Adenosine Receptors (AR): Analgesic and Anti-Inflammatory Effects}

Adenosine, the hydrolysis product of purine nucleotides such as ATP and ADP, often plays the opposite role to them, leading to a compensatory system in physiological and pathological conditions. In fact, endogenous adenosine has modulating effects on neuronal and glial cells with implications in pain transmission. For this reason, adenosine has been proposed as a potential analgesic target for nociceptive, inflammatory, and neuropathic pain. Therefore, the adenosine signaling pathway may be an interesting target to treat endometriosis-associated pain. However, determining the effects of adenosine in endometriosis-associated pain is quite complex. It has been experimentally proven that adenosine can produce antinociceptive and anti-inflammatory effects as well as their opposite, depending on the site of action, the receptor activated, the extent of exposure, and the context.

Although the role of P1 receptors in endometriosis-associated pain has not yet been studied, we briefly outline the different effects that have been described in the literature and their possible usefulness for the treatment of endometriosis-associated pain.

$A_{1}$ adenosine receptor $(A R) . \mathrm{A}_{1} \mathrm{AR}$ is the main adenosine receptor associated with inhibitory neuromodulation of pain. $A_{1} A R$ regulates neurotransmitter release, neuronal excitability, and pain reduction. This high adenosine affinity receptor is expressed at peripheral sensory nerve endings [125], in dorsal horn neurons of the superficial layers of spinal cord [126], and in microglia [127].

$A_{1} A R$ is $G_{i}$-coupled and its activation inhibits AC activity (inhibition of cAMP production), which leads to hyperpolarization by increasing potassium conductance, blocks transient calcium channel opening, and stimulates PLC, inducing an increase in inositol 1,4,5-triphosphate $\left(\mathrm{IP}_{3}\right)$ and intracellular $\mathrm{Ca}^{2+}$ levels and stimulation of calcium-binding proteins such as protein kinase C (PKC) [128]. 
Furthermore, $\mathrm{A}_{1} \mathrm{AR}$ presynaptically inhibits primary sensory neuron transmission onto dorsal spinal neurons by blocking neurotransmitter release $[126,129]$. Moreover, when primary sensory afferent neurons depolarize, afferent nerve terminals release glutamate and SP, but also adenosine, in the dorsal spinal cord [129]. In this situation, adenosine can act as a negative modulator by activating $\mathrm{A}_{1} \mathrm{AR}$ at postsynaptic sites.

As mentioned, $\mathrm{A}_{1} \mathrm{AR}$ is also present in spinal cord microglia where it is upregulated by high levels of extracellular ATP. The activation of $A_{1}$ ARs curbs activation of microglia and blocks their role in neuronal sensitization [127].

Several clinical studies have demonstrated that specific $A_{1}$ AR stimulation results in analgesic effects sufficient to ameliorate nociceptive, neuropathic, and inflammatory pain (reviewed in $[18,130]$ ). This antinociception, and specifically the reduction of hyperalgesia in several pain models, suggests $\mathrm{A}_{1} \mathrm{AR}$ agonists as possible tools for treating endometriosis-associated chronic pain.

$A_{2 A} A R . \mathrm{A}_{2 \mathrm{~A}} \mathrm{AR}$ is present in immune cells, neurons, and glial cells, among other cell types. In fact, $\mathrm{A}_{2 \mathrm{~A}} \mathrm{AR}$ is considered a potential therapeutic target in treating chronic pain of neuroinflammatory origin. $A_{2 A} A R$ action is, however, controversial due to an apparent dichotomy between peripheral and central signaling.

At the molecular level, $A_{2 A}$ ARs are directly coupled to $G_{s}$ intracellular proteins, leading to the activation of AC (activation of CAMP production) with the consequent activation of the protein kinase A (PKA) and PKC signaling cascade. Increased cAMP levels in primary afferent neurons contribute to peripheral sensory nerve stimulation and increased excitatory neurotransmitter release in the spinal cord, enhancing nociception [131].

In addition, $\mathrm{A}_{2 \mathrm{~A}} \mathrm{AR}$ is considered the main mediator of anti-inflammatory responses through its expression in a wide range of immune cells. $\mathrm{A}_{2 \mathrm{~A}} \mathrm{AR}$ activation increases intracellular immunosuppressive cAMP in peripheral immune cells. This may contribute to reducing inflammatory pain by modulating these cells and consequently decreasing the levels of sensitizing substances (e.g., inflammatory cytokines from macrophages or histamine from mast cells) in the endometriotic microenvironment [130].

In addition, $\mathrm{A}_{2 \mathrm{~A}} \mathrm{AR}$ modulates immunoresponses of microglia. As in peripheral immune cells, $\mathrm{A}_{2 \mathrm{~A}} \mathrm{AR}$ agonists produce a cAMP signaling cascade that attenuates pro-inflammatory cytokine production and increases anti-inflammatory cytokine release, mainly IL-10. The reduction of the inflammatory state relieves neurophatic pain [132-135].

Conversely, under pathologic conditions, $\mathrm{A}_{2 \mathrm{~A}} \mathrm{AR}$ activation is also related to a pro-inflammatory role [136,137]. During neuropathic pain, persistent activation of spinal microglia occurs. The sustained release of stimulating molecules such as BDNF in spinal cord exacerbates neuronal hypersensitivity and chronic neuroinflammation. As noted above, ATP mediates BDNF release via P2X4 receptor from activated microglia, as well as by adenosine via $\mathrm{A}_{2 \mathrm{~A}} \mathrm{AR}$. Constitutive release of $\mathrm{BDNF}$ is under the control of $\mathrm{PKC}$, but, in some pathological conditions, upregulation of $\mathrm{A}_{2 \mathrm{~A}} \mathrm{AR}$ in microglia has been detected. The high levels of intracellular cAMP and the subsequent activation of PKA prevails over PKC actions inducing increased BDNF release [137]. However, the increase in $\mathrm{A}_{2 \mathrm{~A}} \mathrm{AR}$ levels in microglia is mainly described in brain with chronic neuroinflammation in cases with neurodegenerative diseases, where $\mathrm{A}_{2 \mathrm{~A}} \mathrm{AR}$ interaction with several neurotransmitters plays an important role in pathology progression [138]. Further studies are needed to determine if $\mathrm{A}_{2 \mathrm{~A}} \mathrm{AR}$ upregulation in activated microglia also occurs in endometriosis-associated pain. If that is the case, the therapeutic strategies involving $\mathrm{A}_{2 \mathrm{~A}} \mathrm{AR}$ activation might not be good for the evolution of chronic pain related with endometriosis.

In conclusion, therapeutic tools that potentiate $\mathrm{A}_{1} \mathrm{AR}$-mediated antinociceptive and $\mathrm{A}_{2 \mathrm{~A}} \mathrm{AR}$-mediated anti-inflammatory actions of adenosine could have analgesic effects that would be useful for the management of endometriosis-associated pain.

$A_{2 B} A R . \mathrm{A}_{2 \mathrm{~B}} \mathrm{AR}$ is mainly present in immune cells, as well as, at low levels, in spinal cord and CNS, and prominently in astrocytes $[18,19]$. Its ubiquitous expression in inflammatory cells suggests a role in inflammatory pain through the release of various inflammatory mediators. 
$\mathrm{A}_{2 \mathrm{~B}} \mathrm{AR}$ has a low affinity for adenosine, and it is therefore significantly activated under pathophysiological conditions, when adenosine concentration is high. Similar to $A_{2 A} A R, A_{2 B} A R$ activates AC, leading to a PKA phosphorylation cascade. This cellular signaling mainly promotes an anti-inflammatory response in immune cells and plays a part in the attenuation of acute inflammation [128].

While it may appear that $A_{2 B} A R$ plays the same role as $A_{2 A} A R$, its effect is sometimes opposed. This is possible because, as with $A_{1}$ and $A_{3} A R, A_{2 B} A R$ is coupled to PLC, leading to the accumulation of intracellular $\mathrm{Ca}^{2+}$, the generation of $\mathrm{IP}_{3}$ and diacylglycerol (DAG), and the activation of PKC, involved in the release of pro-inflammatory mediators such as IL-6 from macrophages and IL-1 $\beta$ and VEGF from mast cells, with indirect effects on inflammatory pain $[19,130,139]$. In fact, Hu et al. described a mechanism underlying $\mathrm{A}_{2 \mathrm{~B}} \mathrm{AR}$-mediated chronic pain in three independent models of chronic pain [140]. The prolonged elevated adenosine levels activate $\mathrm{A}_{2 \mathrm{~B}} \mathrm{ARs}$ of myeloid cells. This activation increases the production and release of IL-6 and soluble IL-6 receptor (sIL-6R). The complex IL-6/sIL-6R trans-activates gp130 on primary sensory fibers, which in turn stimulates the transcription factor pSTAT3, inducing TRPV1 gene transcription. The increase of TRPV1 in nociceptors produces sensory neuron hyperexcitability and can produce chronic inflammatory pain.

These opposing effects of $A_{2 B} A R$ hamper the use of its agonists or antagonists as potential therapeutic agents for inflammatory disorders and pain. Evaluating the possible use of $A_{2 B} A R$ as therapeutic target of endometriosis-associated pain requires a better understanding of the function of $\mathrm{A}_{2 \mathrm{~B}} \mathrm{AR}$ in this disease. Moreover, the loss of expression of some ectonucleotidases in endometriotic tissue and the large amount of ADA in the fluid contents of endometriomas suggests that the adenosine levels in endometriotic milieu are low, rendering activation of $A_{2 B} A R s$ unlikely. Consequently, $A_{2 B} A R$ does not seem to be a suitable target for endometriosis treatment.

$A_{3} A R . \mathrm{A}_{3} \mathrm{ARs}$ are described in peripheral and central neurons, glial cells, and immune cells $[141,142]$. Over the last decades, experimental studies with $A_{3} A R$ agonists showed the attenuation of nociception and neuropathic pain [130,141-143]. This has made $A_{3}$ AR a focus of development of new therapeutic strategies for pain.

Similar to $A_{1} A R, A_{3} A R$ is coupled to $G_{i}$, which inhibits $A C$, and to $G_{q}$, which activates PKC. On primary sensory neurons, $\mathrm{A}_{3} \mathrm{AR}$ inhibits the $\mathrm{Ca}^{2+}$-dependent $\mathrm{K}^{+}$currents, reducing their excitability and neurotransmitter release [142]. This mechanism exerts an antinociceptive effect, but it is not the only one.

Agonists of $\mathrm{A}_{3} \mathrm{AR}$ enhance and recover inhibitory GABA signaling in spinal cord neurons. In neuropathic pain states, reduced levels of spinal GABA and GAD65 [144,145], its synthesis enzyme, are detected, whereas the expression of GABA transporter GAT-1, which uptakes the neurotransmitter from the synapse, is increased [145]. Additionally, there is a reduction in the activity and expression of KCC2. As noted above, P2X4 receptor activation promotes the production and release of BDNF, which, via TrkB, downregulates $\mathrm{KCC} 2$ and disrupts $\mathrm{Cl}^{-}$homeostasis, altering $\mathrm{GABA}_{\mathrm{A}}$ receptor postsynaptic inhibitory control and leading to neuronal hyperexcitability [109-111]. $A_{3} A R$ activation reverses these situations. The use of $\mathrm{A}_{3} \mathrm{AR}$ agonists maintains the phosphorylation status of GAD65 and GAT-1, which stabilizes and activates GAD65 and leads to the internalization and inactivation of GAT-1 [146]. In addition, $\mathrm{A}_{3} \mathrm{AR}$ agonists enhance $\mathrm{KCC} 2$ phosphorylation, increasing its activity [146]. Therefore, the activation of $\mathrm{A}_{3} \mathrm{AR}$ allows the increase of GABA levels and the restoration of inhibitory actions of GABA in the spinal cord, alleviating neuropathic pain. Moreover, $A_{3} A R$ activation also diminishes the production of pro-inflammatory cytokines (TNF- $\alpha$ and IL-1 $\beta$ ) and enhances the formation of anti-inflammatory cytokines (IL-10) in the spinal cord by inhibiting the p38/MAPK and NF- ${ }_{\mathrm{kB}}$ signaling pathways $[143,147,148]$. This enhances the reduction of glial activation, decreasing neuroinflammation and pain hypersensitivity.

In recent years, antinociceptive properties of $\mathrm{A}_{1} \mathrm{AR}$ and $\mathrm{A}_{2 \mathrm{~A}} \mathrm{AR}$ agonists have been the most studied targets of adenosine signaling to relieve acute and chronic pain. However, $A_{3} A R$ agonists have increased in importance in pain treatment since they avoid the undesirable cardiovascular side effects 
of $A_{1} A R$ and $A_{2 A} A R$ agonists $[149,150]$. For this reason, the use of selective $A_{3} A R$ agonists seems promising as a safe and effective analgesic treatment for chronic pain, and it is also being considered to treat endometriosis-associated pain.

\section{Perspectives of ATP and Adenosine Signaling Modulation: Possible Tools to Treat Endometriosis-Associated Pain}

Most medical treatments for endometriosis are aimed at relieving the chronic pain associated with the disease, but in many cases endometriosis-associated pain symptoms are not improved, and, if they are, they return with treatment cessation (reviewed in [53]).

As we try to document in this review, there is clear involvement of purinergic signaling in the generation and modulation of the sensation of pain. ATP participates in the hyperexcitability of sensory neurons and the development and maintenance of different types of pain (nociceptive, inflammatory, and neuropathic). Evidence mostly suggests ATP is responsible for triggering nociceptive pain, as well as inflammatory responses in the body, in contrast to adenosine. ATP also influences fecundation, endometrial receptivity, and embryo implantation [2].

In endometriosis, the adhesion of viable endometrial cells to establish an ectopic endometriotic focus triggers signals of injury and promotes the activation of an immune system that is inefficient in clearing ectopic cells. This situation is reflected in a significant increase in extracellular ATP levels in the endometriotic lesion. The ATP-rich microenvironment of the endometriotic lesion contributes to the two main symptoms of endometriosis: pain and infertility. The increase in ATP levels is enhanced by the loss of expression of certain ectonucleotidases in endometrial ectopic cells, prolonging signaling and activating pain. It seems, then, reasonable that development of therapeutic approaches for endometriosis-associated pain be based on achieving a decrease in ATP levels and their signaling cascade, and/or increased adenosine levels and activation of their receptors. Despite the potential of purinergic-based drugs and their analgesic effects in various pain models, there is no medication presently available for clinical use.

Currently, most pharmacological therapies for endometriosis are hormonal therapies. Neither these nor surgical treatment are compatible with the pregnancy desire of women with endometriosis, and it is usually a matter of choosing between alleviating symptoms and getting pregnant. A non-hormonal alternative to alleviate endometriosis-associated pain may lie in purinergic-based drugs. The development of clinical drugs targeting purinergic receptors is not free of difficulties, such as the ubiquitous expression and wide action of purinergic receptors throughout the body, and the large number of receptor subtypes combined with a lack of complete knowledge of their physiological and pathophysiological functions.

We present below a selection of potential purinergic signaling targets for pharmacological treatment of endometriosis-associated pain, without ruling out their utility in the improvement of the fertility of these women.

\section{(I) P2 Receptor Antagonists}

ATP, through P2X and P2Y receptors, induces cell signaling directly involved in hyperexcitability of sensory neurons and sustained glial cell reactivity in neuropathic pain. P2 receptor antagonists and other molecules that alter their function have been used to describe the involvement of ATP in pain signaling. Moreover, the attenuation of nociception, hyperalgesia, and allodynia by blocking some P2 receptors suggests that $\mathrm{P} 2$ receptor-related drugs are potential candidates for the treatment of chronic pain conditions. In fact, P2X3 receptors of sensory neurons seem to be the main receptors involved in pain, and P2X4 and P2X7 receptors appear to be key elements in neuropathic and inflammatory pain for their function in glial and immune cells.

P2X3 receptor is involved in the development and progression of endometriosis-associated pain $[81,82,86,87]$, and there is a growing interest in the development of substances to interfere or inhibit its function. A P2X3 antagonist, MK-7264/AF-219, known as gefapixant, is currently being 
tested in various advanced clinical trials with subjects with pulmonary disease and chronic cough (NCT01432730, NCT02502097, and NCT02477709). Recently, a clinical trial has been begun to evaluate the efficacy and safety of gefapixant in women with endometriosis-associated pain (NCT03654326). Experimental evidence of the relief of endometriosis-related pain has been obtained with the use of P2X3 receptor antagonists (e.g., A-317491), in endometriosis-induced animal models [87].

The use of P2X4 receptor antagonists (such as CORM-2, 5-BDBD, and NP-1815-PX) and P2X7 receptor antagonists (such as AZD9056 and AZ11645373) has been reported to inhibit microglia activation, significantly reducing inflammation and alleviating pain (reviewed in [151,152]). Although the administration of AZD9056 yielded good results in pain models in animals, clinical trials were not successful in alleviating symptoms in patients with rheumatoid arthritis, a chronic inflammatory disorder [153]. This suggests that new pharmacological strategies with P2X4 and P2X7 as targets are needed to achieve the desired clinical results in the treatment of inflammation and pain in endometriosis.

P2Y receptors are also potential pharmacological targets. For example, $\mathrm{P}_{2} \mathrm{Y}_{12}$ receptor regulates microglial activation and the neurotransmission of the excitatory signal in spinal cord neurons; the administration of $\mathrm{P}_{2} \mathrm{Y}_{12}$ antagonists blocked microglia action in nerve injury-induced pain models $[115,154]$. There are clinical trials with $\mathrm{P}_{2} \mathrm{Y}_{12}$ antagonists, in cardiovascular pathologies, but not yet in pain. However, the antithrombotic actions of $\mathrm{P}_{2} \mathrm{Y}_{12}$ antagonist drugs could certainly complicate their use.

\section{(II) The Control of ATP Release}

ATP release can occur via vesicular and non-vesicular mechanisms. Targeting ATP release on the endometriotic lesions, on sensory and central neurons, would represent a fine-tuning regulation of the $\mathrm{P} 2$ receptors involved in pain.

Vesicular ATP release involves the mechanism of exocytosis. Vesicular nucleotide transporter (VNUT), encoded by SLC17A9 gene, is responsible for the vesicular storage and release of ATP in neurons, astrocytes, and microglia $[155,156]$. It is known that secretion of ATP through VNUT-dependent vesicular release mechanisms is involved in purinergic signaling in pain and inflammation [155].

After peripheral nerve injury, increases in VNUT expression and extracellular ATP levels are detected in spinal cord [156]. Masuda et al. showed that mice lacking VNUT in the dorsal horn neurons reduced the alloydina evoked by peripheral nerve injury. This did not occur with mice lacking VNUT in primary sensory neurons, astrocytes, or microglia. Increased extracellular ATP levels and neuropathic pain were restored in these mice lacking VNUT in dorsal horn neurons when VNUT expression was restored [156].

Clodronate and etidronate are biphosphonates used in osteoporosis therapy that have analgesic properties. In vitro assays demonstrated that they inhibited VNUT, leading to the modulation of ATP release and purinergic transmission [157,158]. In addition, in vivo studies with clodronate showed attenuation of neuropathic and inflammatory pain [158]. As clodronate is approved for clinical use in the treatment of osteoporosis and its safety is proven, it may be a good candidate for the treatment of endometriosis-associated pain.

ATP release in neurons, astrocytes, and microglia also occurs through membrane channels, such as pannexin hemichannels, connexins, and the P2X7 receptor itself. In recent years, a wealth of evidence has pointed to pannexin-1 $[124,159,160]$ and connexin-43 (reviewed in [161-163]) as crucial elements in the induction and maintenance of chronic pain. These ATP-permeable channels are, therefore, pain relief targets for further investigation.

\section{(III) Recombinant Ectonucleotidases}

In endometriosis, a loss of ectonucleotidase expression is reported in association with the severity of the disease. This might contribute to a rise in ATP levels. Restoring the ectonucleotidase activity in the endometriotic tissue would consequently reduce ATP-induced pain and enhance the antinociceptive effects of adenosine in the pain pathway. 
CD39, CD73, and prostatic acid phosphatase (PAP) have been described as the main ectonucleotidases involved in the production of adenosine in DRG and spinal cord neurons $[128,164]$. A single intrathecal injection of recombinant soluble CD73 or PAP had long-lasting antinociceptive effects, dependent on $\mathrm{A}_{1} \mathrm{AR}$ activation, including antihyperalgesic and antiallodynic effects, in naïve mice and in mouse models of inflammatory and neuropathic pain $[165,166]$.

Recombinant ectonucleotidases are potential tools for endometriosis-associated pain treatment. Additional preclinical and clinical studies are required to confirm their benefit in inflammatory and neuropathic pain.

\section{(IV) P1 Receptor Agonists}

Adenosine has a limited use due to its short life in vivo. Alternatively, agonists and positive allosteric modulators of AR have been described as pharmacological tools to treat inflammation and pain (reviewed in [167-169]). Their analgesic and anti-inflammatory effects have been studied with $A_{1} A R, A_{2 A} A R$, and $A_{3} A R$ agonists. The controversial role of $A_{2 B} A R$ limits their therapeutic use.

Several preclinical and clinical trials with agonists of $A_{1} A R$ (e.g., GW493838 and NCT00376454) and $\mathrm{A}_{2 \mathrm{~A}} \mathrm{AR}$ (e.g., BVT.115929 and NCT00452777) have been performed. Despite the good results of AR agonists in several pain models [126,132-135], the lack of analgesia in humans together with the evidence of undesirable side effects, such as cardiovascular involvement, jeopardizes their use in any therapy $[168,169]$.

On the other hand, preclinical and human clinical studies with $A_{3} A R$ agonists did not have significant side effects [170]. Antinociceptive effects have been described with the use of moderately selective agonists of $\mathrm{A}_{3} \mathrm{ARs}$, such as IB-MECA and Cl-IB-MECA, and highly selective agonists, such as MRS5698 and MRS5980. In general, $A_{3} A R$ agonists tend to restore the altered pain signaling of chronic pain. For example, $A_{3} A R$ agonists decrease glial activation and the generation of pro-inflammatory cytokines [143,147,148], increase the production of anti-inflammatory cytokines [147,148], and restore the inhibitory action of GABA [146]. Interestingly, $\mathrm{A}_{3} \mathrm{AR}$ agonists selectively modify pathological pain but seem not to alter protective pain [171]. Phase II and III clinical trials with IB-MECA have been completed in rheumatoid arthritis (NCT01034306) and psoriasis (NCT01265667), respectively. A phase II clinical trial with Cl-IB-MECA was also completed in chronic hepatitis C (NCT00790673). Moreover, Cl-IB-MECA is currently in phase II for its antitumor effects in hepatocellular carcinoma (NCT02128958). Although these clinical trials do not attend to their effectiveness in chronic pain, the safety profile in chronic inflammatory diseases, liver disease, and cancer envisages an optimistic future in the pharmacological treatment of neurophatic endometriosis-associated pain.

Several studies have demonstrated that acupuncture improves endometriosis-associated pain $[54,172,173]$. Interestingly, mechanisms underlying acupuncture-induced analgesia involve purinergic signaling [174-176]. Acupuncture produces local release of ATP leading to the activation of purinoreceptors on sensory nerve endings, triggering the neurotransmission of pain signal to brain. Local release of adenosine in certain centers of the brain cortex can modulate and inhibit pain sensation through the activation of $\mathrm{AR}$, mainly $\mathrm{A}_{1} \mathrm{AR}[175,177]$. Thus, acupuncture is a possible complementary treatment to relieve endometriosis-related pain.

In addition, the potential analgesic effect of adenosine receptor antagonists such as caffeine has also been studied. Caffeine, at low doses, and in combination with analgesic drugs, acts as an adjuvant (reviewed in [178]). At dietary levels, caffeine has a high affinity for $\mathrm{A}_{1}, \mathrm{~A}_{2 \mathrm{~A}}$, and $A_{2 B} A R s$ [179]. Adenosine-based mechanisms involved in caffeine pharmacological antinociception are attributed to the $A_{2 A}$ and $A_{2 B} A R$ blockade [178]. Despite its auspicious effects, caffeine has not been tested in endometriosis-associated pain. In fact, we predict that the use of caffeine in relieving endometriosis-associated pain is a complex matter due to the role of caffeine in female hormone pathways, in turn influencing the endometriosis outcome [180-182]. Moreover, no consistent association has been found between coffee/caffeine intake and the risk of this hormone-dependent disease [183-185]. Furthermore, the inhibition of $A_{1} A R$ by caffeine might interfere with the effectiveness 
of several analgesic agents and treatments, e.g., acupuncture (reviewed in [178]), which should be taken into account in the clinical management of patients.

\section{(V) Inhibitors of Equilibrative Nucleoside Transporters}

In contrast to ATP, adenosine is neither stored nor released in synaptic vesicles. However, adenosine can be released by the cell via nucleoside transporters. One way to increase local extracellular adenosine levels and the concomitant antinociceptive signaling is the blocking of the equilibrative nucleoside transporters (ENTs). ENTs regulate facilitated diffusion and bidirectional nucleoside transport across the cell membrane, following the concentration gradient, in a number of tissues, including central nervous system. ENT-1 is highly expressed in superficial dorsal horn laminae and in DRG, colocalizing with $\mathrm{A}_{1}$ and $\mathrm{A}_{2} \mathrm{AR}[186,187]$.

Maes et al. demonstrated that systemic administration of ENT-1 inhibitors can reverse hyperalgesia in guinea pig inflammatory pain models [188]. The mechanism underlying this analgesia seems to be the blocking of adenosine reuptake into cells, allowing greater activation of $A_{1}$ and $A_{2} A R$ [188]. These results show that it is necessary to investigate the potential therapeutic effect of ENT inhibition. Moreover, the use of ENT inhibitors in combination with AR agonists or ADA inhibitors might enhance the antinociceptive effects of these molecules.

Consequently, the use of ENT inhibitors for analgesia in endometriosis is worth studying.

\section{(VI) Inhibitors of AK and ADA}

Adenosine metabolism is mainly the responsibility of AK and ADA enzymes; their inhibition would result in an increase in local extracellular adenosine levels, enhancing their antinociceptive signaling.

Several studies have shown that the supply of an orally active non-nucleoside AK inhibitor (ABT-702) produced effective antinociceptive and anti-inflammatory effects both in vitro and in vivo [189-191]. Increased adenosine concentration by AK inhibition seems to produce therapeutic effects through the activation of $A_{1}$ and $A_{2 A} A R$ [192]. Moreover, its pharmacological action is achieved with lower doses than with AR agonists, thus reducing the probability of producing psychomotor and cardiovascular side effects. Nevertheless, other AK inhibitors have toxic side effects, such as neurotoxicity (reviewed in [192]). The findings about ABT-702 indicate this to be an efficient and safe drug for the treatment of neuropathic pain and inflammatory states. Studies of the effects of ABT-702 in induced-endometriosis animal models are needed to assess its utility in therapies against endometriosis-associated pain.

It is notable that ADA, another metabolic enzyme of adenosine, and AK have different kinetics: with low or moderate inflammation, $\mathrm{AK}$ is the one modulating adenosine levels; with greater inflammation, where there is a substantial elevation of adenosine levels, ADA activity gains importance [193]. Hence, the effect of their inhibitors would also vary depending on adenosine levels in the environment. While the antinociceptive effect of AK inhibitors has been demonstrated, inhibition of ADA does not produce an intrinsic antinociceptive effect without very high levels of adenosine [194]. This is why the use of ADA inhibitors is only considered as an enhancer of the antinociceptive effects of AK inhibitors [195]. ADA inhibitors, such as deoxycoformycin, have been shown to have anticancer effects and to be useful in the treatment of infectious diseases [196-198]. Unfortunately, these compounds are usually toxic at effective doses [196,198-200]. The co-administration of AK inhibitors, such as ABT-702, with ADA inhibitors at lower doses as adjuvants, seems to be a suitable strategy for analgesia in endometriosis patients, but exhaustive prior safety studies are required.

\section{Conclusions}

Pain has a strong impact on the quality of life of women with endometriosis. Current surgical and pharmacological treatments for endometriosis have as their primary goal the relief of pain. Nevertheless, these treatments have a limited success rate and in general hamper pregnancy. Although there is increasing understanding of the essential role of purinergic signaling in the 
development and progression of nociceptive, inflammatory, and neuropathic pain, its implication in endometriosis-associated pain is still poorly studied. In this review, we examine the role of purinergic signaling, and particularly the role of extracellular ATP as a triggering factor for acute and chronic pain signaling, in the context of endometriosis.

Ectonucleotidases, the enzymes regulating ATP levels in the extracellular milieu, are altered in endometrial tissue in endometriosis. Of note is the decrease in the expression of the CD39-CD73 axis that supports the hypothesis of ATP (rather than adenosine) accumulation. Concomitant sustained activation of $\mathrm{P} 2$ receptors, capable of generating a persistent pain message, is compatible with the onset and maintenance of endometriosis-associated pain. It is known that P2X3 receptor, expressed in sensory neurons, mediates nociceptive, neuropathic, and inflammatory pain, and it is enrolled in endometriosis-related pain; therefore, pharmacological P2X3 inhibition is a worthy candidate for testing; in this sense, the use of the $\mathrm{P} 2 \mathrm{X} 3$ receptor antagonist gefapixant is under clinical study. Although the P2X3 receptor fulfills the requirements to be a suitable molecule to be targeted, other ATP receptors have to be considered as well, such as the P2X4 and P2X7 receptors that are involved in macrophage-nerve and microglia-nerve interactions, promoting a persistent inflammatory state and the chronification of pain. P2X4 receptor triggers the generation of the inflammatory pain sensitization mediator PGE2 and is involved in the decrease of inhibitory control of GABAergic interneurons in neuropathic pain. In contrast, $\mathrm{P} 2 \mathrm{X} 7$ receptor promotes the maintenance of neuropathic pain through the FKN/CX3C/CX3CR1 pathway, which seems to be altered in endometriosis. The use of P2X4 and P2X7 antagonists has yielded good results in reducing inflammation and alleviating pain in animal models. However, a clinical trial with the P2X7 receptor antagonist AZD9056 has been unsuccessful in a chronic inflammatory disorder, rheumatoid arthritis.

$\mathrm{P}_{2} \mathrm{Y}_{1}$ and $\mathrm{P} 2 \mathrm{Y}_{2}$ receptors are involved in the activation and regulation of $\mathrm{P} 2 \mathrm{X} 3$ and TRPV1 receptor ion channels of nociceptors. Moreover, microglial $\mathrm{P}_{2} \mathrm{Y}_{12}$ and $\mathrm{P}_{2} \mathrm{Y}_{13}$ receptors activation triggers the release of pro-inflammatory cytokines, increasing excitatory synaptic transmission in the dorsal horn. Although P2Y receptors are involved in the modulation of pain, there are no clinical trials evaluating the use of P2Y antagonists in pain.

In addition, the antinociceptive and anti-inflammatory actions of the ARs, mainly $A_{1} A R$ and $A_{3} A R$, have encouraged studies using agonists of these receptors for the treatment of pain and chronic inflammatory diseases. With the current knowledge, $\mathrm{A}_{3}$ AR-targeting drugs are potential tools to treat neuropathic pain, as well as endometriosis-associated pain, but clinical studies in this regard are needed.

In summary, purinergic signaling-based strategies need to be further explored in the medical management of endometriosis-associated pain. This will also improve treatment of other symptoms of endometriosis, such as infertility, in which purinergic signaling also plays a role.

Author Contributions: C.T., Writing—original draft preparation; and M.M.-S., Writing—review, and editing. Both authors have read and agreed to the published version of the manuscript.

Funding: This research was funded by the Instituto de Salud Carlos III (grant number: PI18/00541), co-funded by FEDER funds/European Regional Development Fund (ERDF) ("a Way to Build Europe"), FONDOS FEDER ("una manera de hacer Europa"), and a grant from the Fundación Merck Salud (Ayuda Merck de Investigación 2016-Fertilidad).

Acknowledgments: We thank CERCA Programme (Generalitat de Catalunya) for institutional support, and Tom Yohannan for language editing.

Conflicts of Interest: The authors declare no conflict of interest.

\section{References}

1. Nisolle, M.; Donnez, J. Peritoneal endometriosis, ovarian endometriosis, and adenomyotic nodules of the rectovaginal septum are three different entities. Fertil. Steril. 1997, 68, 585-596. [CrossRef]

2. Bulletti, C.; Coccia, M.E.; Battistoni, S.; Borini, A. Endometriosis and infertility. J. Assist. Reprod. Genet. 2010, 27, 441-447. [CrossRef] [PubMed] 
3. May, K.E.; Villar, J.; Kirtley, S.; Kennedy, S.H.; Becker, C.M. Endometrial alterations in endometriosis: A systematic review of putative biomarkers. Hum. Reprod. Update 2011, 17, 637-653. [CrossRef] [PubMed]

4. As-Sanie, S.; Black, R.; Giudice, L.C.; Gray Valbrun, T.; Gupta, J.; Jones, B.; Laufer, M.R.; Milspaw, A.T.; Missmer, S.A.; Norman, A.; et al. Assessing research gaps and unmet needs in endometriosis. Am. J. Obstet. Gynecol. 2019, 221, 86-94. [CrossRef]

5. Sampson, J. Peritoneal endometriosis due to the menstrual dissemination of endometrial tissue into the peritoneal cavity. Am. J. Obstet. Gynecol. 1927, 14, 422-469. [CrossRef]

6. Grandi, G.; Mueller, M.D.; Papadia, A.; Kocbek, V.; Bersinger, N.A.; Petraglia, F.; Cagnacci, A.; McKinnon, B. Inflammation influences steroid hormone receptors targeted by progestins in endometrial stromal cells from women with endometriosis. Am. J. Reprod. Immunol. 2016, 117, 30-38. [CrossRef]

7. Nothnick, W.; Alali, Z. Recent advances in the understanding of endometriosis: The role of inflammatory mediators in disease pathogenesis and treatment. F1000Research 2016, 5. [CrossRef]

8. Ahn, S.H.; Khalaj, K.; Young, S.L.; Lessey, B.A.; Koti, M.; Tayade, C. Immune-inflammation gene signatures in endometriosis patients. Fertil. Steril. 2016, 106, 1420-1431.e7. [CrossRef]

9. Zhang, T.; De Carolis, C.; Man, G.C.W.; Wang, C.C. The link between immunity, autoimmunity and endometriosis: A literature update. Autoimmun. Rev. 2018, 17, 945-955. [CrossRef]

10. Zheng, P.; Zhang, W.; Leng, J.; Lang, J. Research on central sensitization of endometriosis-associated pain: A systematic review of the literature. J. Pain Res. 2019, 12, 1447-1456. [CrossRef]

11. Morotti, M.; Vincent, K.; Becker, C.M. Mechanisms of pain in endometriosis. Eur. J. Obstet. Gynecol. Reprod. Biol. 2017, 209, 8-13. [CrossRef] [PubMed]

12. Yegutkin, G.G. Enzymes involved in metabolism of extracellular nucleotides and nucleosides: Functional implications and measurement of activities. Crit. Rev. Biochem. Mol. Biol. 2014, 49, 473-497. [CrossRef] [PubMed]

13. Volonté, C.; D'Ambrosi, N. Membrane compartments and purinergic signalling: The purinome, a complex interplay among ligands, degrading enzymes, receptors and transporters. FEBS J. 2009, 276, 318-329. [CrossRef] [PubMed]

14. Faas, M.M.; Saez, T.; de Vos, P. Extracellular ATP and adenosine: The Yin and Yang in immune responses? Mol. Asp. Med. 2017, 55, 9-19. [CrossRef] [PubMed]

15. Falzoni, S.; Donvito, G.; Di Virgilio, F. Detecting adenosine triphosphate in the pericellular space. Interface Focus 2013, 3, 20120101. [CrossRef]

16. Zimmermann, H.; Zebisch, M.; Strater, N. Cellular function and molecular structure of ecto-nucleotidases. Purinergic Signal. 2012, 8, 437-502. [CrossRef]

17. Ralevic, V.; Burnstock, G. Receptors for purines and pyrimidines. Pharmacol. Rev. 1998, 50, 413-492.

18. Sawynok, J. Adenosine receptor targets for pain. Neuroscience 2016, 338, 1-18. [CrossRef]

19. Chandrasekaran, B.; Samarneh, S.; Jaber, A.M.Y.; Kassab, G.; Agrawal, N. Therapeutic Potentials of A2B Adenosine Receptor Ligands: Current Status and Perspectives. Curr. Pharm. Des. 2019, 25, 2741-2771. [CrossRef]

20. Schulte, G.; Fredholm, B.B. Signalling from adenosine receptors to mitogen-activated protein kinases. Cell. Signal. 2003, 15, 813-827. [CrossRef]

21. Burnstock, G. Short- and long-term (trophic) purinergic signalling. Philos. Trans. R. Soc. B Biol. Sci. $2016,371$. [CrossRef] [PubMed]

22. Scarfi, S. Purinergic receptors and nucleotide processing ectoenzymes: Their roles in regulating mesenchymal stem cell functions. World J. Stem Cells 2014, 6, 153-162. [CrossRef] [PubMed]

23. Roszek, K.; Wujak, M. How to influence the mesenchymal stem cells fate? Emerging role of ectoenzymes metabolizing nucleotides. J. Cell. Physiol. 2018, 234, 320-334. [CrossRef] [PubMed]

24. Burnstock, G. Purinergic signalling in the reproductive system in health and disease. Purinergic Signal. 2014, 10, 157-187. [CrossRef] [PubMed]

25. Burnstock, G.; Dale, N. Purinergic signalling during development and ageing. Purinergic Signal. 2015, 11, 277-305. [CrossRef]

26. Aliagas, E.; Vidal, A.; Torrejon-Escribano, B.; Taco Mdel, R.; Ponce, J.; de Aranda, I.G.; Sevigny, J.; Condom, E.; Martin-Satue, M. Ecto-nucleotidases distribution in human cyclic and postmenopausic endometrium. Purinergic Signal. 2013, 9, 227-237. [CrossRef] 
27. Villamonte, M.L.; Torrejon-Escribano, B.; Rodriguez-Martinez, A.; Trapero, C.; Vidal, A.; Gomez de Aranda, I.; Sevigny, J.; Matias-Guiu, X.; Martin-Satue, M. Characterization of ecto-nucleotidases in human oviducts with an improved approach simultaneously identifying protein expression and in situ enzyme activity. Histochem. Cell Biol. 2018, 149, 269-276. [CrossRef]

28. Battistone, M.A.; Merkulova, M.; Park, Y.J.; Peralta, M.A.; Gombar, F.; Brown, D.; Breton, S. Unravelling purinergic regulation in the epididymis: Activation of V-ATPase-dependent acidification by luminal ATP and adenosine. J. Physiol. 2019, 597, 1957-1973. [CrossRef]

29. Casali, E.A.; de Souza, L.F.; Gelain, D.P.; Kaiser, G.R.; Battastini, A.M.; Sarkis, J.J. Changes in ectonucleotidase activities in rat Sertoli cells during sexual maturation. Mol. Cell. Biochem. 2003, 247, 111-119. [CrossRef]

30. Kauffenstein, G.; Pelletier, J.; Lavoie, E.G.; Kukulski, F.; Martin-Satue, M.; Dufresne, S.S.; Frenette, J.; Ribas Furstenau, C.; Sereda, M.J.; Toutain, B.; et al. Nucleoside triphosphate diphosphohydrolase-1 ectonucleotidase is required for normal vas deferens contraction and male fertility through maintaining P2X1 receptor function. J. Biol. Chem. 2014, 289, 28629-28639. [CrossRef]

31. Martin-Satue, M.; Lavoie, E.G.; Pelletier, J.; Fausther, M.; Csizmadia, E.; Guckelberger, O.; Robson, S.C.; Sevigny, J. Localization of plasma membrane bound NTPDases in the murine reproductive tract. Histochem. Cell Biol. 2009, 131, 615-628. [CrossRef] [PubMed]

32. Martinez-Ramirez, A.S.; Vazquez-Cuevas, F.G. Purinergic signaling in the ovary. Mol. Reprod. Dev. 2015, 82, 839-848. [CrossRef] [PubMed]

33. Trapero, C.; Vidal, A.; Rodriguez-Martinez, A.; Sevigny, J.; Ponce, J.; Coroleu, B.; Matias-Guiu, X.; Martin-Satue, M. The ectonucleoside triphosphate diphosphohydrolase-2 (NTPDase2) in human endometrium: A novel marker of basal stroma and mesenchymal stem cells. Purinergic Signal. 2019, 15, 225-236. [CrossRef] [PubMed]

34. Lu, D.; Insel, P.A. Cellular mechanisms of tissue fibrosis. 6. Purinergic signaling and response in fibroblasts and tissue fibrosis. Am. J. Physiol. Cell Physiol. 2014, 306, C779-C788. [CrossRef] [PubMed]

35. Burnstock, G. Purinergic Signaling in the Cardiovascular System. Circ. Res. 2017, 120, 207-228. [CrossRef]

36. Burnstock, G.; Verkhratsky, A. Long-term (trophic) purinergic signalling: Purinoceptors control cell proliferation, differentiation and death. Cell Death Dis. 2010, 1, e9. [CrossRef]

37. Trapero, C.; Vidal, A.; Fernandez-Montoli, M.E.; Coroleu, B.; Tresserra, F.; Barri, P.; Gomez de Aranda, I.; Sevigny, J.; Ponce, J.; Matias-Guiu, X.; et al. Impaired Expression of Ectonucleotidases in Ectopic and Eutopic Endometrial Tissue Is in Favor of ATP Accumulation in the Tissue Microenvironment in Endometriosis. Int. J. Mol. Sci. 2019, 20, 5532. [CrossRef]

38. Hood, B.L.; Liu, B.; Alkhas, A.; Shoji, Y.; Challa, R.; Wang, G.; Ferguson, S.; Oliver, J.; Mitchell, D.; Bateman, N.W.; et al. Proteomics of the human endometrial glandular epithelium and stroma from the proliferative and secretory phases of the menstrual cycle. Biol. Reprod. 2015, 92, 106. [CrossRef]

39. Chen, Q.; Xin, A.; Qu, R.; Zhang, W.; Li, L.; Chen, J.; Lu, X.; Gu, Y.; Li, J.; Sun, X. Expression of ENPP3 in human cyclic endometrium: A novel molecule involved in embryo implantation. Reprod. Fertil. Dev. 2018, 30, 1277-1285. [CrossRef]

40. Boggavarapu, N.R.; Lalitkumar, S.; Joshua, V.; Kasvandik, S.; Salumets, A.; Lalitkumar, P.G.; Gemzell-Danielsson, K. Compartmentalized gene expression profiling of receptive endometrium reveals progesterone regulated ENPP3 is differentially expressed and secreted in glycosylated form. Sci. Rep. 2016, 6, 33811. [CrossRef]

41. Texido, L.; Romero, C.; Vidal, A.; Garcia-Valero, J.; Fernandez Montoli, M.E.; Baixeras, N.; Condom, E.; Ponce, J.; Garcia-Tejedor, A.; Martin-Satue, M. Ecto-nucleotidases activities in the contents of ovarian endometriomas: Potential biomarkers of endometriosis. Mediat. Inflamm. 2014, 2014, 120673. [CrossRef] [PubMed]

42. Leone, R.D.; Emens, L.A. Targeting adenosine for cancer immunotherapy. J. Immunother. Cancer 2018, 6, 57. [CrossRef] [PubMed]

43. Aliagas, E.; Vidal, A.; Texido, L.; Ponce, J.; Condom, E.; Martin-Satue, M. High expression of ecto-nucleotidases CD39 and CD73 in human endometrial tumors. Mediat. Inflamm. 2014, 2014, 509027. [CrossRef] [PubMed]

44. Trapero, C.; Jover, L.; Fernandez-Montoli, M.E.; Garcia-Tejedor, A.; Vidal, A.; Gomez de Aranda, I.; Ponce, J.; Matias-Guiu, X.; Martin-Satue, M. Analysis of the ectoenzymes ADA, ALP, ENPP1, and ENPP3, in the contents of ovarian endometriomas as candidate biomarkers of endometriosis. Am. J. Reprod. Immunol. 2018, 79. [CrossRef] 
45. Busacca, M.; Chiaffarino, F.; Candiani, M.; Vignali, M.; Bertulessi, C.; Oggioni, G.; Parazzini, F. Determinants of long-term clinically detected recurrence rates of deep, ovarian, and pelvic endometriosis. Am. J. Obstet. Gynecol. 2006, 195, 426-432. [CrossRef] [PubMed]

46. Dai, Y.; Leng, J.H.; Lang, J.H.; Li, X.Y.; Zhang, J.J. Anatomical distribution of pelvic deep infiltrating endometriosis and its relationship with pain symptoms. Chin. Med. J. 2012, 125, 209-213. [PubMed]

47. Rush, G.; Misajon, R. Examining subjective wellbeing and health-related quality of life in women with endometriosis. Health Care Women Int. 2018, 39, 303-321. [CrossRef]

48. Facchin, F.; Barbara, G.; Dridi, D.; Alberico, D.; Buggio, L.; Somigliana, E.; Saita, E.; Vercellini, P. Mental health in women with endometriosis: Searching for predictors of psychological distress. Hum. Reprod. 2017, 32, 1855-1861. [CrossRef]

49. Coxon, L.; Horne, A.W.; Vincent, K. Pathophysiology of endometriosis-associated pain: A review of pelvic and central nervous system mechanisms. Best Pract. Res. Clin. Obstet. Gynaecol. 2018, 51, 53-67. [CrossRef]

50. Vercellini, P.; Vigano, P.; Somigliana, E.; Fedele, L. Endometriosis: Pathogenesis and treatment. Nat. Rev. Endocrinol. 2014, 10, 261-275. [CrossRef]

51. Aredo, J.V.; Heyrana, K.J.; Karp, B.I.; Shah, J.P.; Stratton, P. Relating Chronic Pelvic Pain and Endometriosis to Signs of Sensitization and Myofascial Pain and Dysfunction. Semin. Reprod. Med. 2017, 35, 88-97. [CrossRef] [PubMed]

52. Rolla, E. Endometriosis: Advances and controversies in classification, pathogenesis, diagnosis, and treatment. F1000Research 2019, 8. [CrossRef] [PubMed]

53. Becker, C.M.; Gattrell, W.T.; Gude, K.; Singh, S.S. Reevaluating response and failure of medical treatment of endometriosis: A systematic review. Fertil. Steril. 2017, 108, 125-136. [CrossRef] [PubMed]

54. Xu, Y.; Zhao, W.; Li, T.; Zhao, Y.; Bu, H.; Song, S. Effects of acupuncture for the treatment of endometriosis-related pain: A systematic review and meta-analysis. PLoS ONE 2017, 12, e0186616. [CrossRef]

55. Brown, J.; Crawford, T.J.; Allen, C.; Hopewell, S.; Prentice, A. Nonsteroidal anti-inflammatory drugs for pain in women with endometriosis. Cochrane Database Syst. Rev. 2017, 1, Cd004753. [CrossRef]

56. Singh, S.S.; Suen, M.W. Surgery for endometriosis: Beyond medical therapies. Fertil. Steril. 2017, 107, 549-554. [CrossRef]

57. Chaichian, S.; Kabir, A.; Mehdizadehkashi, A.; Rahmani, K.; Moghimi, M.; Moazzami, B. Comparing the Efficacy of Surgery and Medical Therapy for Pain Management in Endometriosis: A Systematic Review and Meta-analysis. Pain Physician 2017, 20, 185-195.

58. Kim, J.H.; Han, E. Endometriosis and Female Pelvic Pain. Semin. Reprod. Med. 2018, 36, 143-151. [CrossRef]

59. Andres, M.P.; Borrelli, G.M.; Abrao, M.S. Endometriosis classification according to pain symptoms: Can the ASRM classification be improved? Best Pract. Res. Clin. Obstet. Gynaecol. 2018, 51, 111-118. [CrossRef]

60. Brown, J.; Crawford, T.J.; Datta, S.; Prentice, A. Oral contraceptives for pain associated with endometriosis. Cochrane Database Syst. Rev. 2018, 5, Cd001019. [CrossRef]

61. Vercellini, P.; Buggio, L.; Frattaruolo, M.P.; Borghi, A.; Dridi, D.; Somigliana, E. Medical treatment of endometriosis-related pain. Best Pract. Res. Clin. Obstet. Gynaecol. 2018, 51, 68-91. [CrossRef] [PubMed]

62. Flyckt, R.; Kim, S.; Falcone, T. Surgical Management of Endometriosis in Patients with Chronic Pelvic Pain. Semin. Reprod. Med. 2017, 35, 54-64. [CrossRef] [PubMed]

63. Yan, D.; Liu, X.; Guo, S.W. Nerve fibers and endometriotic lesions: Partners in crime in inflicting pains in women with endometriosis. Eur. J. Obstet. Gynecol. Reprod. Biol. 2017, 209, 14-24. [CrossRef] [PubMed]

64. Bele, T.; Fabbretti, E. P2X receptors, sensory neurons and pain. Curr. Med. Chem. 2015, 22, 845-850. [CrossRef]

65. Burnstock, G. Purinergic Mechanisms and Pain. Adv. Pharmacol. 2016, 75, 91-137. [CrossRef]

66. Inoue, K. Purinergic signaling in microglia in the pathogenesis of neuropathic pain. Proc. Jpn. Acad. Ser. B Phys. Biol. Sci. 2017, 93, 174-182. [CrossRef]

67. Magni, G.; Ceruti, S. The role of adenosine and P2Y receptors expressed by multiple cell types in pain transmission. Brain Res. Bull. 2019. [CrossRef]

68. Magni, G.; Riccio, D.; Ceruti, S. Tackling Chronic Pain and Inflammation through the Purinergic System. Curr. Med. Chem. 2018, 25, 3830-3865. [CrossRef]

69. Tsuda, M. P2 receptors, microglial cytokines and chemokines, and neuropathic pain. J. Neurosci. Res. 2017, 95, 1319-1329. [CrossRef]

70. Kuan, Y.H.; Shyu, B.C. Nociceptive transmission and modulation via P2X receptors in central pain syndrome. Mol. Brain 2016, 9, 58. [CrossRef] 
71. Liang, Y.; Xie, H.; Wu, J.; Liu, D.; Yao, S. Villainous role of estrogen in macrophage-nerve interaction in endometriosis. Reprod. Biol. Endocrinol. 2018, 16, 122. [CrossRef] [PubMed]

72. Inoue, K.; Tsuda, M. Microglia in neuropathic pain: Cellular and molecular mechanisms and therapeutic potential. Nat. Rev. Neurosci. 2018, 19, 138-152. [CrossRef] [PubMed]

73. Scholz, J.; Woolf, C.J. The neuropathic pain triad: Neurons, immune cells and glia. Nat. Neurosci. 2007, 10, 1361-1368. [CrossRef]

74. Tokushige, N.; Markham, R.; Russell, P.; Fraser, I.S. Nerve fibres in peritoneal endometriosis. Hum. Reprod. 2006, 21, 3001-3007. [CrossRef] [PubMed]

75. Tokushige, N.; Russell, P.; Black, K.; Barrera, H.; Dubinovsky, S.; Markham, R.; Fraser, I.S. Nerve fibers in ovarian endometriomas. Fertil. Steril. 2010, 94, 1944-1947. [CrossRef]

76. Zhang, X.; Yao, H.; Huang, X.; Lu, B.; Xu, H.; Zhou, C. Nerve fibres in ovarian endometriotic lesions in women with ovarian endometriosis. Hum. Reprod. 2010, 25, 392-397. [CrossRef]

77. Wang, G.; Tokushige, N.; Markham, R.; Fraser, I.S. Rich innervation of deep infiltrating endometriosis. Hum. Reprod. 2009, 24, 827-834. [CrossRef]

78. Arnold, J.; Barcena de Arellano, M.L.; Ruster, C.; Vercellino, G.F.; Chiantera, V.; Schneider, A.; Mechsner, S. Imbalance between sympathetic and sensory innervation in peritoneal endometriosis. Brain Behav. Immun. 2012, 26, 132-141. [CrossRef]

79. Ueno, S.; Tsuda, M.; Iwanaga, T.; Inoue, K. Cell type-specific ATP-activated responses in rat dorsal root ganglion neurons. Br. J. Pharmacol. 1999, 126, 429-436. [CrossRef]

80. Chen, Y.; Li, G.W.; Wang, C.; Gu, Y.; Huang, L.Y. Mechanisms underlying enhanced P2X receptor-mediated responses in the neuropathic pain state. Pain 2005, 119, 38-48. [CrossRef]

81. Greaves, E.; Grieve, K.; Horne, A.W.; Saunders, P.T. Elevated peritoneal expression and estrogen regulation of nociceptive ion channels in endometriosis. J. Clin. Endocrinol. Metab. 2014, 99, E1738-E1743. [CrossRef] [PubMed]

82. Ding, S.; Zhu, L.; Tian, Y.; Zhu, T.; Huang, X.; Zhang, X. P2X3 receptor involvement in endometriosis pain via ERK signaling pathway. PLoS ONE 2017, 12, e0184647. [CrossRef] [PubMed]

83. Bele, T.; Fabbretti, E. The scaffold protein calcium/calmodulin-dependent serine protein kinase controls ATP release in sensory ganglia upon P2X3 receptor activation and is part of an ATP keeper complex. J. Neurochem. 2016, 138, 587-597. [CrossRef] [PubMed]

84. Stratton, P.; Khachikyan, I.; Sinaii, N.; Ortiz, R.; Shah, J. Association of chronic pelvic pain and endometriosis with signs of sensitization and myofascial pain. Obstet. Gynecol. 2015, 125, 719-728. [CrossRef] [PubMed]

85. Nakagawa, T.; Wakamatsu, K.; Zhang, N.; Maeda, S.; Minami, M.; Satoh, M.; Kaneko, S. Intrathecal administration of ATP produces long-lasting allodynia in rats: Differential mechanisms in the phase of the induction and maintenance. Neuroscience 2007, 147, 445-455. [CrossRef]

86. Ding, S.; Yu, Q.; Wang, J.; Zhu, L.; Li, T.; Guo, X.; Zhang, X. Activation of ATF3/AP-1 signaling pathway is required for P2X3-induced endometriosis pain. Hum. Reprod. 2020, 35, 1130-1144. [CrossRef]

87. Yuan, M.; Ding, S.; Meng, T.; Lu, B.; Shao, S.; Zhang, X.; Yuan, H.; Hu, F. Effect of A-317491 delivered by glycolipid-like polymer micelles on endometriosis pain. Int. J. Nanomed. 2017, 12, 8171-8183. [CrossRef]

88. Tsudo, T.; Harada, T.; Iwabe, T.; Tanikawa, M.; Nagano, Y.; Ito, M.; Taniguchi, F.; Terakawa, N. Altered gene expression and secretion of interleukin-6 in stromal cells derived from endometriotic tissues. Fertil. Steril. 2000, 73, 205-211. [CrossRef]

89. Wei, X.; Shao, X. Nobiletin alleviates endometriosis via down-regulating NF- $\mathrm{kB}$ activity in endometriosis mouse model. Biosci. Rep. 2018, 38. [CrossRef]

90. Yu, J.; Francisco, A.M.C.; Patel, B.G.; Cline, J.M.; Zou, E.; Berga, S.L.; Taylor, R.N. IL-1 $\beta$ Stimulates Brain-Derived Neurotrophic Factor Production in Eutopic Endometriosis Stromal Cell Cultures: A Model for Cytokine Regulation of Neuroangiogenesis. Am. J. Pathol. 2018, 188, 2281-2292. [CrossRef]

91. Makabe, T.; Koga, K.; Miyashita, M.; Takeuchi, A.; Sue, F.; Taguchi, A.; Urata, Y.; Izumi, G.; Takamura, M.; Harada, M.; et al. Drospirenone reduces inflammatory cytokines, vascular endothelial growth factor (VEGF) and nerve growth factor (NGF) expression in human endometriotic stromal cells. J. Reprod. Immunol. 2017, 119, 44-48. [CrossRef] [PubMed]

92. Lin, J.; Li, G.; Den, X.; Xu, C.; Liu, S.; Gao, Y.; Liu, H.; Zhang, J.; Li, X.; Liang, S. VEGF and its receptor-2 involved in neuropathic pain transmission mediated by $\mathrm{P}_{2} \mathrm{X}_{2 / 3}$ receptor of primary sensory neurons. Brain Res. Bull. 2010, 83, 284-291. [CrossRef] [PubMed] 
93. Ye, Y.; Ono, K.; Bernabé, D.G.; Viet, C.T.; Pickering, V.; Dolan, J.C.; Hardt, M.; Ford, A.P.; Schmidt, B.L. Adenosine triphosphate drives head and neck cancer pain through P2X2/3 heterotrimers. Acta Neuropathol. Commun. 2014, 2, 62. [CrossRef] [PubMed]

94. Yan, D.; Liu, X.; Guo, S.W. Neuropeptides Substance P and Calcitonin Gene Related Peptide Accelerate the Development and Fibrogenesis of Endometriosis. Sci. Rep. 2019, 9, 2698. [CrossRef] [PubMed]

95. Kritas, S.K.; Caraffa, A.; Antinolfi, P.; Saggini, A.; Pantalone, A.; Rosati, M.; Tei, M.; Speziali, A.; Saggini, R.; Pandolfi, F.; et al. Nerve growth factor interactions with mast cells. Int. J. Immunopathol. Pharmacol. 2014, 27, 15-19. [CrossRef] [PubMed]

96. Zhu, T.H.; Ding, S.J.; Li, T.T.; Zhu, L.B.; Huang, X.F.; Zhang, X.M. Estrogen is an important mediator of mast cell activation in ovarian endometriomas. Reproduction 2018, 155, 73-83. [CrossRef]

97. Theoharides, T.C.; Tsilioni, I.; Bawazeer, M. Mast Cells, Neuroinflammation and Pain in Fibromyalgia Syndrome. Front. Cell. Neurosci. 2019, 13, 353. [CrossRef]

98. Zhu, H.; Yu, Y.; Zheng, L.; Wang, L.; Li, C.; Yu, J.; Wei, J.; Wang, C.; Zhang, J.; Xu, S.; et al. Chronic inflammatory pain upregulates expression of P2Y2 receptor in small-diameter sensory neurons. Metab. Brain Dis. 2015, 30, 1349-1358. [CrossRef]

99. Chen, X.; Molliver, D.C.; Gebhart, G.F. The P2Y2 receptor sensitizes mouse bladder sensory neurons and facilitates purinergic currents. J. Neurosci. 2010, 30, 2365-2372. [CrossRef]

100. Kwon, S.G.; Roh, D.H.; Yoon, S.Y.; Moon, J.Y.; Choi, S.R.; Choi, H.S.; Kang, S.Y.; Han, H.J.; Beitz, A.J.; Oh, S.B.; et al. Acid evoked thermal hyperalgesia involves peripheral P2Y1 receptor mediated TRPV1 phosphorylation in a rodent model of thrombus induced ischemic pain. Mol. Pain 2014, 10, 2. [CrossRef]

101. Kwon, S.G.; Roh, D.H.; Yoon, S.Y.; Moon, J.Y.; Choi, S.R.; Choi, H.S.; Kang, S.Y.; Han, H.J.; Beitz, A.J.; Lee, J.H. Blockade of peripheral P2Y1 receptors prevents the induction of thermal hyperalgesia via modulation of TRPV1 expression in carrageenan-induced inflammatory pain rats: Involvement of p38 MAPK phosphorylation in DRGs. Neuropharmacology 2014, 79, 368-379. [CrossRef] [PubMed]

102. Luo, Y.; Feng, C.; Wu, J.; Wu, Y.; Liu, D.; Dai, F.; Zhang, J. P2Y1, P2Y2, and TRPV1 Receptors Are Increased in Diarrhea-Predominant Irritable Bowel Syndrome and P2Y2 Correlates with Abdominal Pain. Dig. Dis. Sci. 2016, 61, 2878-2886. [CrossRef] [PubMed]

103. Lakshmi, S.; Joshi, P.G. Co-activation of P2Y2 receptor and TRPV channel by ATP: Implications for ATP induced pain. Cell. Mol. Neurobiol. 2005, 25, 819-832. [CrossRef] [PubMed]

104. Munrós, J.; Tàssies, D.; Reverter, J.C.; Martin, L.; Pérez, A.; Carmona, F.; Martínez-Zamora, M. Circulating Neutrophil Extracellular Traps Are Elevated in Patients With Deep Infiltrating Endometriosis. Reprod. Sci. 2019, 26, 70-76. [CrossRef]

105. Oliveira-Fusaro, M.C.; Gregory, N.S.; Kolker, S.J.; Rasmussen, L.; Allen, L.H.; Sluka, K.A. P2X4 Receptors on Muscle Macrophages Are Required for Development of Hyperalgesia in an Animal Model of Activity-Induced Muscle Pain. Mol. Neurobiol. 2020, 57, 1917-1929. [CrossRef]

106. Janks, L.; Sprague, R.S.; Egan, T.M. ATP-Gated P2X7 Receptors Require Chloride Channels To Promote Inflammation in Human Macrophages. J. Immunol. 2019, 202, 883-898. [CrossRef]

107. Ulmann, L.; Hirbec, H.; Rassendren, F. P2X4 receptors mediate PGE2 release by tissue-resident macrophages and initiate inflammatory pain. EMBO J. 2010, 29, 2290-2300. [CrossRef]

108. Possover, M. Five-Year Follow-Up After Laparoscopic Large Nerve Resection for Deep Infiltrating Sciatic Nerve Endometriosis. J. Minim. Invasive Gynecol. 2017, 24, 822-826. [CrossRef]

109. Coull, J.A.; Beggs, S.; Boudreau, D.; Boivin, D.; Tsuda, M.; Inoue, K.; Gravel, C.; Salter, M.W.; De Koninck, Y. BDNF from microglia causes the shift in neuronal anion gradient underlying neuropathic pain. Nature 2005, 438, 1017-1021. [CrossRef]

110. Ulmann, L.; Hatcher, J.P.; Hughes, J.P.; Chaumont, S.; Green, P.J.; Conquet, F.; Buell, G.N.; Reeve, A.J.; Chessell, I.P.; Rassendren, F. Up-regulation of P2X4 receptors in spinal microglia after peripheral nerve injury mediates BDNF release and neuropathic pain. J. Neurosci. 2008, 28, 11263-11268. [CrossRef]

111. Long, T.; He, W.; Pan, Q.; Zhang, S.; Zhang, D.; Qin, G.; Chen, L.; Zhou, J. Microglia P2X4R-BDNF signalling contributes to central sensitization in a recurrent nitroglycerin-induced chronic migraine model. J. Headache Pain 2020, 21, 4. [CrossRef] 
112. Xu, F.; Yang, J.; Lu, F.; Liu, R.; Zheng, J.; Zhang, J.; Cui, W.; Wang, C.; Zhou, W.; Wang, Q.; et al. Fast Green FCF Alleviates Pain Hypersensitivity and Down-Regulates the Levels of Spinal P2X4 Expression and Pro-inflammatory Cytokines in a Rodent Inflammatory Pain Model. Front. Pharmacol. 2018, 9, 534. [CrossRef] [PubMed]

113. Ji, R.R.; Chamessian, A.; Zhang, Y.Q. Pain regulation by non-neuronal cells and inflammation. Science 2016, 354, 572-577. [CrossRef] [PubMed]

114. Liu, P.W.; Yue, M.X.; Zhou, R.; Niu, J.; Huang, D.J.; Xu, T.; Luo, P.; Liu, X.H.; Zeng, J.W. P2Y 12 and P2Y 13 receptors involved in ADP $\beta$ s induced the release of IL- $1 \beta$, IL- 6 and TNF- $\alpha$ from cultured dorsal horn microglia. J. Pain Res. 2017, 10, 1755-1767. [CrossRef]

115. Yu, T.; Zhang, X.; Shi, H.; Tian, J.; Sun, L.; Hu, X.; Cui, W.; Du, D. P2Y12 regulates microglia activation and excitatory synaptic transmission in spinal lamina II neurons during neuropathic pain in rodents. Cell Death Dis. 2019, 10, 165. [CrossRef] [PubMed]

116. Shieh, C.H.; Heinrich, A.; Serchov, T.; van Calker, D.; Biber, K. P2X7-dependent, but differentially regulated release of IL-6, CCL2, and TNF- $\alpha$ in cultured mouse microglia. Glia 2014, 62, 592-607. [CrossRef] [PubMed]

117. Garré, J.M.; Yang, G.; Bukauskas, F.F.; Bennett, M.V. FGF-1 Triggers Pannexin-1 Hemichannel Opening in Spinal Astrocytes of Rodents and Promotes Inflammatory Responses in Acute Spinal Cord Slices. J. Neurosci. 2016, 36, 4785-4801. [CrossRef]

118. Sorge, R.E.; Trang, T.; Dorfman, R.; Smith, S.B.; Beggs, S.; Ritchie, J.; Austin, J.S.; Zaykin, D.V.; Vander Meulen, H.; Costigan, M.; et al. Genetically determined P2X7 receptor pore formation regulates variability in chronic pain sensitivity. Nat. Med. 2012, 18, 595-599. [CrossRef]

119. Clark, A.K.; Yip, P.K.; Grist, J.; Gentry, C.; Staniland, A.A.; Marchand, F.; Dehvari, M.; Wotherspoon, G.; Winter, J.; Ullah, J.; et al. Inhibition of spinal microglial cathepsin $\mathrm{S}$ for the reversal of neuropathic pain. Proc. Natl. Acad. Sci. USA 2007, 104, 10655-10660. [CrossRef]

120. Clark, A.K.; Yip, P.K.; Malcangio, M. The liberation of fractalkine in the dorsal horn requires microglial cathepsin S. J. Neurosci. 2009, 29, 6945-6954. [CrossRef]

121. Clark, A.K.; Wodarski, R.; Guida, F.; Sasso, O.; Malcangio, M. Cathepsin S release from primary cultured microglia is regulated by the P2X7 receptor. Glia 2010, 58, 1710-1726. [CrossRef] [PubMed]

122. Liu, Z.; Chen, S.; Qiu, C.; Sun, Y.; Li, W.; Jiang, J.; Zhang, J.M. Fractalkine/CX3CR1 Contributes to Endometriosis-Induced Neuropathic Pain and Mechanical Hypersensitivity in Rats. Front. Cell. Neurosci. 2018, 12, 495. [CrossRef] [PubMed]

123. Hou, X.X.; Zhou, W.J.; Wang, X.Q.; Li, D.J. Fractalkine/CX3CR1 is involved in the pathogenesis of endometriosis by regulating endometrial stromal cell proliferation and invasion. Am. J. Reprod. Immunol. 2016, 76, 318-325. [CrossRef] [PubMed]

124. Mousseau, M.; Burma, N.E.; Lee, K.Y.; Leduc-Pessah, H.; Kwok, C.H.T.; Reid, A.R.; O’Brien, M.; Sagalajev, B.; Stratton, J.A.; Patrick, N.; et al. Microglial pannexin-1 channel activation is a spinal determinant of joint pain. Sci. Adv. 2018, 4, eaas9846. [CrossRef] [PubMed]

125. Katz, N.K.; Ryals, J.M.; Wright, D.E. Central or peripheral delivery of an adenosine A1 receptor agonist improves mechanical allodynia in a mouse model of painful diabetic neuropathy. Neuroscience 2015, 285, 312-323. [CrossRef]

126. Imlach, W.L.; Bhola, R.F.; May, L.T.; Christopoulos, A.; Christie, M.J. A Positive Allosteric Modulator of the Adenosine A1 Receptor Selectively Inhibits Primary Afferent Synaptic Transmission in a Neuropathic Pain Model. Mol. Pharmacol. 2015, 88, 460-468. [CrossRef]

127. Luongo, L.; Guida, F.; Imperatore, R.; Napolitano, F.; Gatta, L.; Cristino, L.; Giordano, C.; Siniscalco, D.; Di Marzo, V.; Bellini, G.; et al. The A1 adenosine receptor as a new player in microglia physiology. Glia 2014, 62, 122-132. [CrossRef]

128. Borea, P.A.; Gessi, S.; Merighi, S.; Vincenzi, F.; Varani, K. Pharmacology of Adenosine Receptors: The State of the Art. Physiol. Rev. 2018, 98, 1591-1625. [CrossRef]

129. El-Hashim, A.Z.; Mathews, S.; Al-Shamlan, F. Central adenosine $A_{1}$ receptors inhibit cough via suppression of excitatory glutamatergic and tachykininergic neurotransmission. Br. J. Pharmacol. 2018, 175, 3162-3174. [CrossRef]

130. Effendi, W.I.; Nagano, T.; Kobayashi, K.; Nishimura, Y. Focusing on Adenosine Receptors as a Potential Targeted Therapy in Human Diseases. Cells 2020, 9, 785. [CrossRef] 
131. Li, Z.H.; Cui, D.; Qiu, C.J.; Song, X.J. Cyclic nucleotide signaling in sensory neuron hyperexcitability and chronic pain after nerve injury. Neurobiol. Pain 2019, 6, 100028. [CrossRef] [PubMed]

132. Loram, L.C.; Taylor, F.R.; Strand, K.A.; Harrison, J.A.; Rzasalynn, R.; Sholar, P.; Rieger, J.; Maier, S.F.; Watkins, L.R. Intrathecal injection of adenosine 2A receptor agonists reversed neuropathic allodynia through protein kinase (PK)A/PKC signaling. Brain Behav. Immun. 2013, 33, 112-122. [CrossRef] [PubMed]

133. Loram, L.C.; Harrison, J.A.; Sloane, E.M.; Hutchinson, M.R.; Sholar, P.; Taylor, F.R.; Berkelhammer, D.; Coats, B.D.; Poole, S.; Milligan, E.D.; et al. Enduring reversal of neuropathic pain by a single intrathecal injection of adenosine 2A receptor agonists: A novel therapy for neuropathic pain. J. Neurosci. 2009, 29, 14015-14025. [CrossRef] [PubMed]

134. Kwilasz, A.J.; Green Fulgham, S.M.; Ellis, A.; Patel, H.P.; Duran-Malle, J.C.; Favret, J.; Harvey, L.O.; Rieger, J.; Maier, S.F.; Watkins, L.R. A single peri-sciatic nerve administration of the adenosine 2A receptor agonist ATL313 produces long-lasting anti-allodynia and anti-inflammatory effects in male rats. Brain Behav. Immun. 2019, 76, 116-125. [CrossRef]

135. Kwilasz, A.J.; Ellis, A.; Wieseler, J.; Loram, L.; Favret, J.; McFadden, A.; Springer, K.; Falci, S.; Rieger, J.; Maier, S.F.; et al. Sustained reversal of central neuropathic pain induced by a single intrathecal injection of adenosine A2A receptor agonists. Brain Behav. Immun. 2018, 69, 470-479. [CrossRef]

136. Meng, F.; Guo, Z.; Hu, Y.; Mai, W.; Zhang, Z.; Zhang, B.; Ge, Q.; Lou, H.; Guo, F.; Chen, J.; et al. CD73-derived adenosine controls inflammation and neurodegeneration by modulating dopamine signalling. Brain 2019, 142, 700-718. [CrossRef]

137. Gomes, C.; Ferreira, R.; George, J.; Sanches, R.; Rodrigues, D.I.; Gonçalves, N.; Cunha, R.A. Activation of microglial cells triggers a release of brain-derived neurotrophic factor (BDNF) inducing their proliferation in an adenosine A2A receptor-dependent manner: A2A receptor blockade prevents BDNF release and proliferation of microglia. J. Neuroinflamm. 2013, 10, 16. [CrossRef]

138. Cunha, R.A. How does adenosine control neuronal dysfunction and neurodegeneration? J. Neurochem. 2016, 139, 1019-1055. [CrossRef]

139. Feoktistov, I.; Biaggioni, I. Role of adenosine A(2B) receptors in inflammation. Adv. Pharmacol. 2011, 61, 115-144. [CrossRef]

140. Hu, X.; Adebiyi, M.G.; Luo, J.; Sun, K.; Le, T.T.; Zhang, Y.; Wu, H.; Zhao, S.; Karmouty-Quintana, H.; Liu, H.; et al. Sustained Elevated Adenosine via ADORA2B Promotes Chronic Pain through Neuro-immune Interaction. Cell Rep. 2016, 16, 106-119. [CrossRef]

141. Janes, K.; Symons-Liguori, A.M.; Jacobson, K.A.; Salvemini, D. Identification of A3 adenosine receptor agonists as novel non-narcotic analgesics. Br. J. Pharmacol. 2016, 173, 1253-1267. [CrossRef] [PubMed]

142. Coppi, E.; Cherchi, F.; Fusco, I.; Failli, P.; Vona, A.; Dettori, I.; Gaviano, L.; Lucarini, E.; Jacobson, K.A.; Tosh, D.K.; et al. Adenosine A3 receptor activation inhibits pronociceptive $\mathrm{N}$-type Ca2+ currents and cell excitability in dorsal root ganglion neurons. Pain 2019, 160, 1103-1118. [CrossRef] [PubMed]

143. Terayama, R.; Tabata, M.; Maruhama, K.; Iida, S. $A_{3}$ adenosine receptor agonist attenuates neuropathic pain by suppressing activation of microglia and convergence of nociceptive inputs in the spinal dorsal horn. Exp. Brain Res. 2018, 236, 3203-3213. [CrossRef]

144. Lorenzo, L.E.; Magnussen, C.; Bailey, A.L.; St Louis, M.; De Koninck, Y.; Ribeiro-da-Silva, A. Spatial and temporal pattern of changes in the number of GAD65-immunoreactive inhibitory terminals in the rat superficial dorsal horn following peripheral nerve injury. Mol. Pain 2014, 10, 57. [CrossRef] [PubMed]

145. Ge, M.M.; Chen, S.P.; Zhou, Y.Q.; Li, Z.; Tian, X.B.; Gao, F.; Manyande, A.; Tian, Y.K.; Yang, H. The therapeutic potential of GABA in neuron-glia interactions of cancer-induced bone pain. Eur. J. Pharmacol. 2019, 858, 172475. [CrossRef]

146. Ford, A.; Castonguay, A.; Cottet, M.; Little, J.W.; Chen, Z.; Symons-Liguori, A.M.; Doyle, T.; Egan, T.M.; Vanderah, T.W.; De Koninck, Y.; et al. Engagement of the GABA to KCC2 signaling pathway contributes to the analgesic effects of A3AR agonists in neuropathic pain. J. Neurosci. 2015, 35, 6057-6067. [CrossRef] [PubMed]

147. Janes, K.; Esposito, E.; Doyle, T.; Cuzzocrea, S.; Tosh, D.K.; Jacobson, K.A.; Salvemini, D. A3 adenosine receptor agonist prevents the development of paclitaxel-induced neuropathic pain by modulating spinal glial-restricted redox-dependent signaling pathways. Pain 2014, 155, 2560-2567. [CrossRef] 
148. Janes, K.; Wahlman, C.; Little, J.W.; Doyle, T.; Tosh, D.K.; Jacobson, K.A.; Salvemini, D. Spinal neuroimmune activation is independent of T-cell infiltration and attenuated by $\mathrm{A} 3$ adenosine receptor agonists in a model of oxaliplatin-induced peripheral neuropathy. Brain Behav. Immun. 2015, 44, 91-99. [CrossRef]

149. Zylka, M.J. Pain-relieving prospects for adenosine receptors and ectonucleotidases. Trends Mol. Med. 2011, 17, 188-196. [CrossRef]

150. Guerrero, A. A2A Adenosine Receptor Agonists and their Potential Therapeutic Applications. An Update. Curr. Med. Chem. 2018, 25, 3597-3612. [CrossRef]

151. Zhang, W.J.; Zhu, Z.M.; Liu, Z.X. The role of P2X4 receptor in neuropathic pain and its pharmacological properties. Pharmacol. Res. 2020, 158, 104875. [CrossRef] [PubMed]

152. Zhang, W.J.; Zhu, Z.M.; Liu, Z.X. The role and pharmacological properties of the P2X7 receptor in neuropathic pain. Brain Res. Bull. 2020, 155, 19-28. [CrossRef] [PubMed]

153. Keystone, E.C.; Wang, M.M.; Layton, M.; Hollis, S.; McInnes, I.B.; Team, D.C.S. Clinical evaluation of the efficacy of the P2X7 purinergic receptor antagonist AZD9056 on the signs and symptoms of rheumatoid arthritis in patients with active disease despite treatment with methotrexate or sulphasalazine. Ann. Rheum. Dis. 2012, 71, 1630-1635. [CrossRef] [PubMed]

154. Horváth, G.; Gölöncsér, F.; Csölle, C.; Király, K.; Andó, R.D.; Baranyi, M.; Koványi, B.; Máté, Z.; Hoffmann, K.; Algaier, I.; et al. Central P2Y12 receptor blockade alleviates inflammatory and neuropathic pain and cytokine production in rodents. Neurobiol. Dis. 2014, 70, 162-178. [CrossRef]

155. Moriyama, Y.; Hiasa, M.; Sakamoto, S.; Omote, H.; Nomura, M. Vesicular nucleotide transporter (VNUT): Appearance of an actress on the stage of purinergic signaling. Purinergic Signal. 2017, 13, 387-404. [CrossRef]

156. Masuda, T.; Ozono, Y.; Mikuriya, S.; Kohro, Y.; Tozaki-Saitoh, H.; Iwatsuki, K.; Uneyama, H.; Ichikawa, R.; Salter, M.W.; Tsuda, M.; et al. Dorsal horn neurons release extracellular ATP in a VNUT-dependent manner that underlies neuropathic pain. Nat. Commun. 2016, 7, 12529. [CrossRef]

157. Yamagata, R.; Nemoto, W.; Nakagawasai, O.; Hung, W.Y.; Shima, K.; Endo, Y.; Tan-No, K. Etidronate attenuates tactile allodynia by spinal ATP release inhibition in mice with partial sciatic nerve ligation. Naunyn Schmiedeberg Arch. Pharmacol. 2019, 392, 349-357. [CrossRef]

158. Kato, Y.; Hiasa, M.; Ichikawa, R.; Hasuzawa, N.; Kadowaki, A.; Iwatsuki, K.; Shima, K.; Endo, Y.; Kitahara, Y.; Inoue, T.; et al. Identification of a vesicular ATP release inhibitor for the treatment of neuropathic and inflammatory pain. Proc. Natl. Acad. Sci. USA 2017, 114, E6297-E6305. [CrossRef]

159. Yamakita, S.; Horii, Y.; Takemura, H.; Matsuoka, Y.; Yamashita, A.; Yamaguchi, Y.; Matsuda, M.; Sawa, T.; Amaya, F. Synergistic activation of ERK1/2 between A-fiber neurons and glial cells in the DRG contributes to pain hypersensitivity after tissue injury. Mol. Pain 2018, 14, 1744806918767508. [CrossRef]

160. Zhang, Y.; Laumet, G.; Chen, S.R.; Hittelman, W.N.; Pan, H.L. Pannexin-1 Up-regulation in the Dorsal Root Ganglion Contributes to Neuropathic Pain Development. J. Biol. Chem. 2015, 290, 14647-14655. [CrossRef]

161. Wang, A.; Xu, C. The role of connexin43 in neuropathic pain induced by spinal cord injury. Acta Biochim. Biophys. Sin. 2019, 51, 555-561. [CrossRef] [PubMed]

162. Morioka, N.; Nakamura, Y.; Zhang, F.F.; Hisaoka-Nakashima, K.; Nakata, Y. Role of Connexins in Chronic Pain and Their Potential as Therapeutic Targets for Next-Generation Analgesics. Biol. Pharm. Bull. 2019, 42, 857-866. [CrossRef] [PubMed]

163. Spray, D.C.; Hanani, M. Gap junctions, pannexins and pain. Neurosci. Lett. 2019, 695, 46-52. [CrossRef] [PubMed]

164. Street, S.E.; Walsh, P.L.; Sowa, N.A.; Taylor-Blake, B.; Guillot, T.S.; Vihko, P.; Wightman, R.M.; Zylka, M.J. PAP and NT5E inhibit nociceptive neurotransmission by rapidly hydrolyzing nucleotides to adenosine. Mol. Pain 2011, 7, 80. [CrossRef]

165. Sowa, N.A.; Vadakkan, K.I.; Zylka, M.J. Recombinant mouse PAP has pH-dependent ectonucleotidase activity and acts through A(1)-adenosine receptors to mediate antinociception. PLoS ONE 2009, 4, e4248. [CrossRef]

166. Sowa, N.A.; Voss, M.K.; Zylka, M.J. Recombinant ecto-5'-nucleotidase (CD73) has long lasting antinociceptive effects that are dependent on adenosine A1 receptor activation. Mol. Pain 2010, 6, 20. [CrossRef]

167. Deb, P.K.; Deka, S.; Borah, P.; Abed, S.N.; Klotz, K.N. Medicinal Chemistry and Therapeutic Potential of Agonists, Antagonists and Allosteric Modulators of A1 Adenosine Receptor: Current Status and Perspectives. Curr. Pharm. Des. 2019, 25, 2697-2715. [CrossRef] 
168. Jacobson, K.A.; Tosh, D.K.; Jain, S.; Gao, Z.G. Historical and Current Adenosine Receptor Agonists in Preclinical and Clinical Development. Front. Cell. Neurosci. 2019, 13, 124. [CrossRef]

169. Jacobson, K.A.; Giancotti, L.A.; Lauro, F.; Mufti, F.; Salvemini, D. Treatment of chronic neuropathic pain: Purine receptor modulation. Pain 2020, 161, 1425-1441. [CrossRef]

170. Jacobson, K.A.; Merighi, S.; Varani, K.; Borea, P.A.; Baraldi, S.; Aghazadeh Tabrizi, M.; Romagnoli, R.; Baraldi, P.G.; Ciancetta, A.; Tosh, D.K.; et al. A 3 Adenosine Receptors as Modulators of Inflammation: From Medicinal Chemistry to Therapy. Med. Res. Rev. 2018, 38, 1031-1072. [CrossRef]

171. Little, J.W.; Ford, A.; Symons-Liguori, A.M.; Chen, Z.; Janes, K.; Doyle, T.; Xie, J.; Luongo, L.; Tosh, D.K.; Maione, S.; et al. Endogenous adenosine A3 receptor activation selectively alleviates persistent pain states. Brain 2015, 138, 28-35. [CrossRef] [PubMed]

172. Mira, T.A.A.; Buen, M.M.; Borges, M.G.; Yela, D.A.; Benetti-Pinto, C.L. Systematic review and meta-analysis of complementary treatments for women with symptomatic endometriosis. Int. J. Gynecol. Obstet. 2018, 143, 2-9. [CrossRef] [PubMed]

173. Liang, R.; Li, P.; Peng, X.; Xu, L.; Fan, P.; Peng, J.; Zhou, X.; Xiao, C.; Jiang, M. Efficacy of acupuncture on pelvic pain in patients with endometriosis: Study protocol for a randomized, single-blind, multi-center, placebo-controlled trial. Trials 2018, 19, 314. [CrossRef] [PubMed]

174. Burnstock, G. Acupuncture: A novel hypothesis for the involvement of purinergic signalling. Med. Hypotheses 2009, 73, 470-472. [CrossRef]

175. Tang, Y.; Yin, H.Y.; Rubini, P.; Illes, P. Acupuncture-Induced Analgesia: A Neurobiological Basis in Purinergic Signaling. Neuroscientist 2016, 22, 563-578. [CrossRef]

176. Zhang, Y.; Huang, L.; Kozlov, S.A.; Rubini, P.; Tang, Y.; Illes, P. Acupuncture alleviates acid- and purine-induced pain in rodents. Br. J. Pharmacol. 2020, 177, 77-92. [CrossRef]

177. Goldman, N.; Chen, M.; Fujita, T.; Xu, Q.; Peng, W.; Liu, W.; Jensen, T.K.; Pei, Y.; Wang, F.; Han, X.; et al. Adenosine A1 receptors mediate local anti-nociceptive effects of acupuncture. Nat. Neurosci. 2010, 13, 883-888. [CrossRef]

178. Sawynok, J. Caffeine and pain. Pain 2011, 152, 726-729. [CrossRef]

179. Fredholm, B.B.; Bättig, K.; Holmén, J.; Nehlig, A.; Zvartau, E.E. Actions of caffeine in the brain with special reference to factors that contribute to its widespread use. Pharmacol. Rev. 1999, 51, 83-133.

180. Kwak, Y.; Choi, H.; Bae, J.; Choi, Y.Y.; Roh, J. Peri-pubertal high caffeine exposure increases ovarian estradiol production in immature rats. Reprod. Toxicol. 2017, 69, 43-52. [CrossRef]

181. Klonoff-Cohen, H.; Bleha, J.; Lam-Kruglick, P. A prospective study of the effects of female and male caffeine consumption on the reproductive endpoints of IVF and gamete intra-Fallopian transfer. Hum. Reprod. 2002, 17, 1746-1754. [CrossRef] [PubMed]

182. Lucero, J.; Harlow, B.L.; Barbieri, R.L.; Sluss, P.; Cramer, D.W. Early follicular phase hormone levels in relation to patterns of alcohol, tobacco, and coffee use. Fertil. Steril. 2001, 76, 723-729. [CrossRef]

183. Hemmert, R.; Schliep, K.C.; Willis, S.; Peterson, C.M.; Louis, G.B.; Allen-Brady, K.; Simonsen, S.E.; Stanford, J.B.; Byun, J.; Smith, K.R. Modifiable life style factors and risk for incident endometriosis. Paediatr. Perinat. Epidemiol. 2019, 33, 19-25. [CrossRef] [PubMed]

184. Chiaffarino, F.; Bravi, F.; Cipriani, S.; Parazzini, F.; Ricci, E.; Viganò, P.; La Vecchia, C. Coffee and caffeine intake and risk of endometriosis: A meta-analysis. Eur. J. Nutr. 2014, 53, 1573-1579. [CrossRef] [PubMed]

185. Parazzini, F.; Viganò, P.; Candiani, M.; Fedele, L. Diet and endometriosis risk: A literature review. Reprod. Biomed. Online 2013, 26, 323-336. [CrossRef]

186. Governo, R.J.; Deuchars, J.; Baldwin, S.A.; King, A.E. Localization of the NBMPR-sensitive equilibrative nucleoside transporter, ENT1, in the rat dorsal root ganglion and lumbar spinal cord. Brain Res. 2005, 1059, 129-138. [CrossRef]

187. Choca, J.I.; Proudfit, H.K.; Green, R.D. Identification of A1 and A2 adenosine receptors in the rat spinal cord. J. Pharmacol. Exp. Ther. 1987, 242, 905-910.

188. Maes, S.S.; Pype, S.; Hoffmann, V.L.; Biermans, M.; Meert, T.F. Antihyperalgesic activity of nucleoside transport inhibitors in models of inflammatory pain in guinea pigs. J. Pain Res. 2012, 5, 391-400. [CrossRef]

189. Suzuki, R.; Stanfa, L.C.; Kowaluk, E.A.; Williams, M.; Jarvis, M.F.; Dickenson, A.H. The effect of ABT-702, a novel adenosine kinase inhibitor, on the responses of spinal neurones following carrageenan inflammation and peripheral nerve injury. Br. J. Pharmacol. 2001, 132, 1615-1623. [CrossRef] 
190. Jarvis, M.F.; Yu, H.; Kohlhaas, K.; Alexander, K.; Lee, C.H.; Jiang, M.; Bhagwat, S.S.; Williams, M.; Kowaluk, E.A. ABT-702 (4-amino-5-(3-bromophenyl)-7-(6-morpholinopyridin-3-yl)pyrido[2, 3-d]pyrimidine), a novel orally effective adenosine kinase inhibitor with analgesic and anti-inflammatory properties: I. In vitro characterization and acute antinociceptive effects in the mouse. J. Pharmacol. Exp. Ther. 2000, 295, 1156-1164.

191. Kowaluk, E.A.; Mikusa, J.; Wismer, C.T.; Zhu, C.Z.; Schweitzer, E.; Lynch, J.J.; Lee, C.H.; Jiang, M.; Bhagwat, S.S.; Gomtsyan, A.; et al. ABT-702 (4-amino-5-(3-bromophenyl)-7-(6-morpholino-pyridin3-yl)pyrido[2,3-d]pyrimidine), a novel orally effective adenosine kinase inhibitor with analgesic and anti-inflammatory properties. II. In vivo characterization in the rat. J. Pharmacol. Exp. Ther. 2000, 295, 1165-1174. [PubMed]

192. Jarvis, M.F. Therapeutic potential of adenosine kinase inhibition-Revisited. Pharmacol. Res. Perspect. 2019, 7, e00506. [CrossRef] [PubMed]

193. Liu, X.J.; White, T.D.; Sawynok, J. Potentiation of formalin-evoked adenosine release by an adenosine kinase inhibitor and an adenosine deaminase inhibitor in the rat hind paw: A microdialysis study. Eur. J. Pharmacol. 2000, 408, 143-152. [CrossRef]

194. Keil, G.J.; DeLander, G.E. Adenosine kinase and adenosine deaminase inhibition modulate spinal adenosineand opioid agonist-induced antinociception in mice. Eur. J. Pharmacol. 1994, 271, 37-46. [CrossRef]

195. Poon, A.; Sawynok, J. Antinociceptive and anti-inflammatory properties of an adenosine kinase inhibitor and an adenosine deaminase inhibitor. Eur. J. Pharmacol. 1999, 384, 123-138. [CrossRef]

196. Yoshikawa, N.; Nakamura, K.; Yamaguchi, Y.; Kagota, S.; Shinozuka, K.; Kunitomo, M. Reinforcement of antitumor effect of Cordyceps sinensis by 2 '-deoxycoformycin, an adenosine deaminase inhibitor. In Vivo 2007, 21, 291-295.

197. Bennett, M.; Matutes, E.; Gaulard, P. Hepatosplenic T cell lymphoma responsive to 2'-deoxycoformycin therapy. Am. J. Hematol. 2010, 85, 727-729. [CrossRef]

198. Spiers, A.S. Deoxycoformycin (pentostatin): Clinical pharmacology, role in the chemotherapy of cancer, and use in other diseases. Haematologia 1996, 27, 55-84.

199. Todd, S.A.; Morris, T.C.; Alexander, H.D. Myelodysplasia terminating in acute myeloid leukemia in a hairy cell leukemia patient treated with 2-deoxycoformycin. Leuk. Lymphoma 2002, 43, 1343-1344. [CrossRef]

200. Dalla Rosa, L.; Da Silva, A.S.; Oliveira, C.B.; Gressler, L.T.; Arnold, C.B.; Baldissera, M.D.; Sagrillo, M.; Sangoi, M.; Moresco, R.; Mendes, R.E.; et al. Dose finding of 3'deoxyadenosine and deoxycoformycin for the treatment of Trypanosoma evansi infection: An effective and nontoxic dose. Microb. Pathog. 2015, 85, 21-28. [CrossRef]

Publisher's Note: MDPI stays neutral with regard to jurisdictional claims in published maps and institutional affiliations.

(C) 2020 by the authors. Licensee MDPI, Basel, Switzerland. This article is an open access article distributed under the terms and conditions of the Creative Commons Attribution (CC BY) license (http://creativecommons.org/licenses/by/4.0/). 